\title{
Supply chain strategy in the luxury fashion industry: impacts on performance indicators
}

\author{
Bianca Bindi \\ University of Florence, Florence, Italy and \\ Università degli Studi di Firenze, Florence, Italy \\ Romeo Bandinelli \\ Università degli Studi di Firenze, Florence, Italy \\ Virginia Fani \\ University of Florence, Florence, Italy and \\ Università degli Studi di Firenze, Florence, Italy, and \\ Margherita Emma Paola Pero \\ Politecnico di Milano, Milan, Italy
}

\begin{abstract}
Purpose - The purpose of this paper was to investigate what types of supply chain strategies (SCS) are implemented within luxury fashion companies, according to the drivers that regulate competitiveness in this sector (brand positioning, distribution channel, type and line of product). Moreover, the objective was to define which key performance indicators (KPIs) should be measured according to the chosen strategy, and finally to evaluate the alignment of luxury fashion companies with the proposed indicators.

Design/methodology/approach - The literature review was the first step performed. Thereafter, a case study was conducted and the sample, composed of six companies, was selected, a questionnaire was then developed to guide the interviews, after which the data were collected. From the data, a primary case analysis was conducted, from which cross-case patterns were also researched.

Findings - From the results obtained, it was possible to state that companies involved in the case study adopted different SCS within the same company according to the drivers that regulate the sector competitiveness. As a result, the product line was shown to be the only driver that affected both the alignment between the expected and implemented SCS, respectively, and the alignment with the selected KPIs.

Originality/value - The paper provides valuable insights to companies that are trying to align SCS and KPIs. The close link between these aspects had not yet been explored previously. In particular, there were no indications about the KPIs that have to be measured for a specific SCS.
\end{abstract}

Keywords Supply chain strategies, SCS, Key performance indicators, KPIs, Fashion, Information

Paper type Research paper

\section{Introduction}

The luxury fashion (apparel and footwear) and leather goods accounted for $50 \%$ of the luxury goods revenue in 2021. The worldwide revenue in 2021 are estimated to be US\$150 billion ('Luxury Fashion - Worldwide | Statista Market Forecast', 2021). In particular, luxury fashion and leather goods industry in Europe is expected to overcome US $\$ 55$ billion, attained by more than 185,000 companies comprising 2 million employees ("Luxury Fashion - Europe | Statista Market Forecast", 2021).

(C) Bianca Bindi, Romeo Bandinelli, Virginia Fani and Margherita Emma Paola Pero. Published in International Journal of Productivity and Performance Management. Published by Emerald Publishing Limited. This article is published under the Creative Commons Attribution (CC BY 4.0) licence. Anyone may reproduce, distribute, translate and create derivative works of this article (for both commercial and non-commercial purposes), subject to full attribution to the original publication and authors. The full terms of this licence may be seen at http://creativecommons.org/licences/by/4.0/legalcode

Received 18 February 2021 Revised 6 September 2021 14 September 2021 Accepted 26 September 2021

luxury fashion industry 
The luxury fashion sector represents a distinct example within the manufacturing industry, showing several characteristics rendering it difficult for the management of both the productive and logistic processes. In particular, three principle aspects have been identified (Christopher et al., 2004). The first aspect pertains to the short product life cycle of the fashion product designed to capture the current mood of the moment. The second relates to the unpredictable and volatile demand of customers that are subject to complete change within a relatively short period of time (Wang et al., 2012). Finally, there is the impulsive purchasing behavior (Newman and Foxall, 2003), attributable to the nature of fashion shoppers as well as the impulsiveness surrounding their purchase behavior.

The strong competitiveness within this sector has led many companies to undertake initiatives in rationalizing the operating processes, aimed at improving the ability to respond to the continuous changes in customer demand, while simultaneously, improving both the efficiency and speed of the entire supply chain (SC) (Vona, 2003).

Therefore, in the face of the constant changes in consumer needs, successful companies can be defined as those with the ability to respond to these rapid changes by reducing lead time (Christopher and Peck, 2004). Within this context, there is the need to define an SCS that can maximize the performance of fashion companies. The SCS is defined as a set of management methods and activities by which a SC obtains advantages over competitors (Brun and Castelli, 2008). It is necessary to specify that, when talking about an SCS, there is no "one best way" or best choice in any specific case. Rather it is an approach that depends on both the internal characteristics of the company as well as the environmental characteristics (Lee, 2003). Therefore, in order to define the correct SCS, it is necessary to, firstly, identify the context in which the SCS has to compete and then define the objectives of the single SC.

The definition of the SCS is strongly linked to the issue of performance monitoring, in order to assess whether the strategy is implemented correctly and to direct the SC toward strategic objectives. For the fashion sector, the literature provides information about various SCS and performance indicators (Brun et al.., 2017; Brun and Castelli, 2008). However, the close link between the two concepts has not yet been explored. In particular, there is no evidence regarding the types of performance indicators that have to be measured for a specific SCS.

Based on a literature analysis and case studies, the present article aims to provide necessary information to fashion luxury companies regarding the type SCS that should be implemented, based on the factors that regulate competitiveness in this sector. Moreover, the article also aims to identify the correct KPIs to measure, according to the chosen strategy.

In total, two research questions (RQ) are, therefore, addressed in the present article:

(1) What types of SCS are currently adopted by fashion companies and why are these strategies adopted?

(2) Which KPIs should be measured by fashion companies according to the SCS identified in RQ1?

The contribution of this article includes:

(1) Investigating what types of SCS are implemented within fashion companies and understanding the reasons why companies choose to implement these strategies.

(2) Defining which performance indicators should be used to measure luxury fashion companies in relation to the strategy adopted and the evaluation of the alignment of luxury fashion companies with the proposed indicators.

Given this background, the paper has been developed as follows. Section 2 presents a literature review on the SCS implemented within the fashion companies and the factors that influence these choices, as well as the KPIs measured within fashion companies. Section 3 
outlines the RQ and methodology, also introducing the principle features of the companies involved in the case studies performed. Section 4 and Section 5 present the findings and analysis of these results, respectively. Finally, section 6 offers some concluding remarks with suggestions for further developments.

\section{Literature review}

\subsection{Supply chain strategy}

Regarding the SCS strategies proposed in the literature, particular attention should be paid to the characteristics between lean and agile strategies, mentioned in all papers regarding this topic, as well as the hybrid strategy that results from the combination of the two aforementioned strategies.

The lean SCS (Table 1) is aimed at creating a cost-efficient SC, by effectively managing inventory and focusing on improving the quality in the SC (Cagnazzo et al, 2010), thus eliminating waste (Huang et al., 2002; Christopher and Towill, 2002). Christopher and Peck (2004)

\begin{tabular}{|c|c|c|c|}
\hline Strategy & Characteristics & References & \\
\hline Lean & $\begin{array}{l}\text { - Minimizing supply chain costs } \\
\text { - Elimination of waste or non-value-added } \\
\text { activities across the chain } \\
\text { - Supplier attributes involve low cost and high } \\
\text { quality } \\
\text { - High inventory turnover } \\
\text { - Low inventory level } \\
\text { - Shortens lead time as long as it does not } \\
\text { increase cost } \\
\text { - High average utilization rate } \\
\text { - Maximizes performance and minimizes cost }\end{array}$ & $\begin{array}{l}\text { Huang } \text { et al. (2002), Wang et al. (2004), } \\
\text { Vonderembse } \text { et al. (2006), Christopher (2000), } \\
\text { Christopher and Towill (2002), Lee (2003), } \\
\text { Qi et al. (2009) }\end{array}$ & \\
\hline Agile & $\begin{array}{l}\text { - Market responsiveness } \\
\text { - Production flexibility } \\
\text { - Adaptability to customer needs } \\
\text { - Supplier attributes involve speed, flexibility, } \\
\text { and quality } \\
\text { - Deploys significant stocks of parts to tide over } \\
\text { unpredictable market requirements } \\
\text { - Invests aggressively in ways to reduce lead } \\
\text { times } \\
\text { - Deploys excess buffer capacity to ensure that } \\
\text { raw material/components are available to } \\
\text { manufacture the product according to market } \\
\text { requirements }\end{array}$ & $\begin{array}{l}\text { Huang et al. (2002), Christopher and Towill } \\
\text { (2000), Wang et al. (2004), Vonderembse et al. } \\
\text { (2006), Christopher (2000), Van Hoek et al. } \\
\text { (2001), Lin et al. (2006), Agarwal et al. (2007), } \\
\text { Towill and Christopher (2002), Power et al. } \\
\text { (2001), Lee (2003), Qi et al. (2009) }\end{array}$ & \\
\hline Hybrid & $\begin{array}{l}\text { - Interfaces with the market to understand } \\
\text { customer requirements, maintaining future } \\
\text { adaptability } \\
\text { - Tries to achieve mass customization by } \\
\text { postponing product differentiation } \\
\text { - Supplier attributes involve low cost and high } \\
\text { quality, along with the capability for speed and } \\
\text { flexibility, as and when required } \\
\text { - Is similar to the lean supply chain at } \\
\text { component level (shorten lead-time but not at } \\
\text { the expense of cost). At product level, } \\
\text { accommodates customer requirements, it } \\
\text { follows that of an agile supply chain }\end{array}$ & $\begin{array}{l}\text { Huang et al. (2002), Naylor et al. (1999), Wang } \\
\text { et al. (2004), Vonderembse et al. (2006), Towill } \\
\text { and Christopher (2002), Christopher (2000) }\end{array}$ & $\begin{array}{r}\text { Table } 1 . \\
\text { Supply chain strategies }\end{array}$ \\
\hline
\end{tabular}


have argued that lean SCs perform well under conditions where demand is relatively stable and predictable, and variety is low.

On the other hand, an agile SCS is aimed at being flexible by adapting quickly and effectively to rapidly changing customer needs (Christopher et al., 2004; Huang et al., 2002; Christopher and Towill, 2002; Lin et al., 2006). Effectiveness is the primary goal of this strategy. Finally, the hybrid strategy is derived from the combination of the two aforementioned strategies. In the hybrid SCS, the practice employed to ensure adaptability to the constant changing customer demands is that of postponement (Cagnazzo et al., 2010). The latter strategy is aimed at moving the differentiation of the product downstream to the final assembly, and as a consequence closer to the customer (Mason-Jones et al., 2000). In particular, the decoupling point (DP), is the point at which real demand penetrates upstream in a SC. Christopher and Towill (2002) contend that processes are designed to be lean up until the DP and agile beyond that point, respectively. Therefore, the hybrid strategy pursues the cost effectiveness up until the DP and the high service level, necessary in the volatile marketplace, downstream of that point (Christopher, 2000).

Depending on the positioning of the DP, different order fulfillment strategies can be defined, for instance make to stock (MTS), in which the SC activities are based on forecasts, and make to order (MTO), in which the supply chain activities are triggered by orders (Wortmann, 1992). In line with Christopher and Towill (2002), lean SC strategies are expected to be mostly associated to MTS situations, while agile for MTO. Interestingly, given the SC perspective of the paper, the term lean is used to consider the entire SCS, not the specific tools used in each stage of the SC, differently from operations management literature that is traditionally focusing on the techniques, such as Kanban systems (Slack et al., 2010), used within a factory.

\subsection{Factors that influence the choice of a supply chain strategy}

From an analysis of the literature, there is the possibility of implementing, within a single company, multiple SCS on the basis of factors that drive the competition, namely brand positioning, distribution channel, type of product (Brun and Castelli, 2008) and line of product (Brun et al., 2008). Based on these four factors, a company is in a position to make various decisions. These decisions may include the application of the same strategy to the entire SC, the application of a different strategy based on one factor (i.e. business segment), selecting an intermediate level, thereby segmenting the SCS on the basis of two of the proposed factors and finally segmenting the SCS according to all four factors proposed (Brun and Castelli, 2008). In addition, from this segmentation, it is possible to understand the hierarchy of the four factors (i.e. which is the main determinant of the strategic segmentation).

Table 2 reports the four factors and highlights how these can influence the choice of the SCS.

\subsection{Link between supply chain strategies and key performance indicators}

The KPIs can be defined as the physical values which are used to measure, compare and manage the overall organizational performance (Gosselin, 2005). The KPIs may include the quality (De Toni and Tonchia, 2001; Gosselin, 2005; Badri et al., 1995; Neely et al., 2005), cost (De Toni and Tonchia, 2001; Neely et al., 2005; White, 1996), financial (Parmenter, 2015; White, 1996), flexibility (De Toni and Tonchia, 2001; and White, 1996), delivery reliability (White, 1996), employee satisfaction (Leong et al., 1990; Ishaq Bhatti and Awan, 2014; Parmenter, 2015), customer satisfaction (Ittner and Larcker, 1998 and Neely et al., 2005; Parmenter, 2015), safety (Flin et al., 2000; Mearns et al., 2003; Parmenter, 2015), environment/community (Neely et al., 2005; Parmenter, 2015; White, 1996) and learning and growth (Parmenter, 2015; SadlerSmith et al., 2001; Utterback and Abernathy, 1975). 

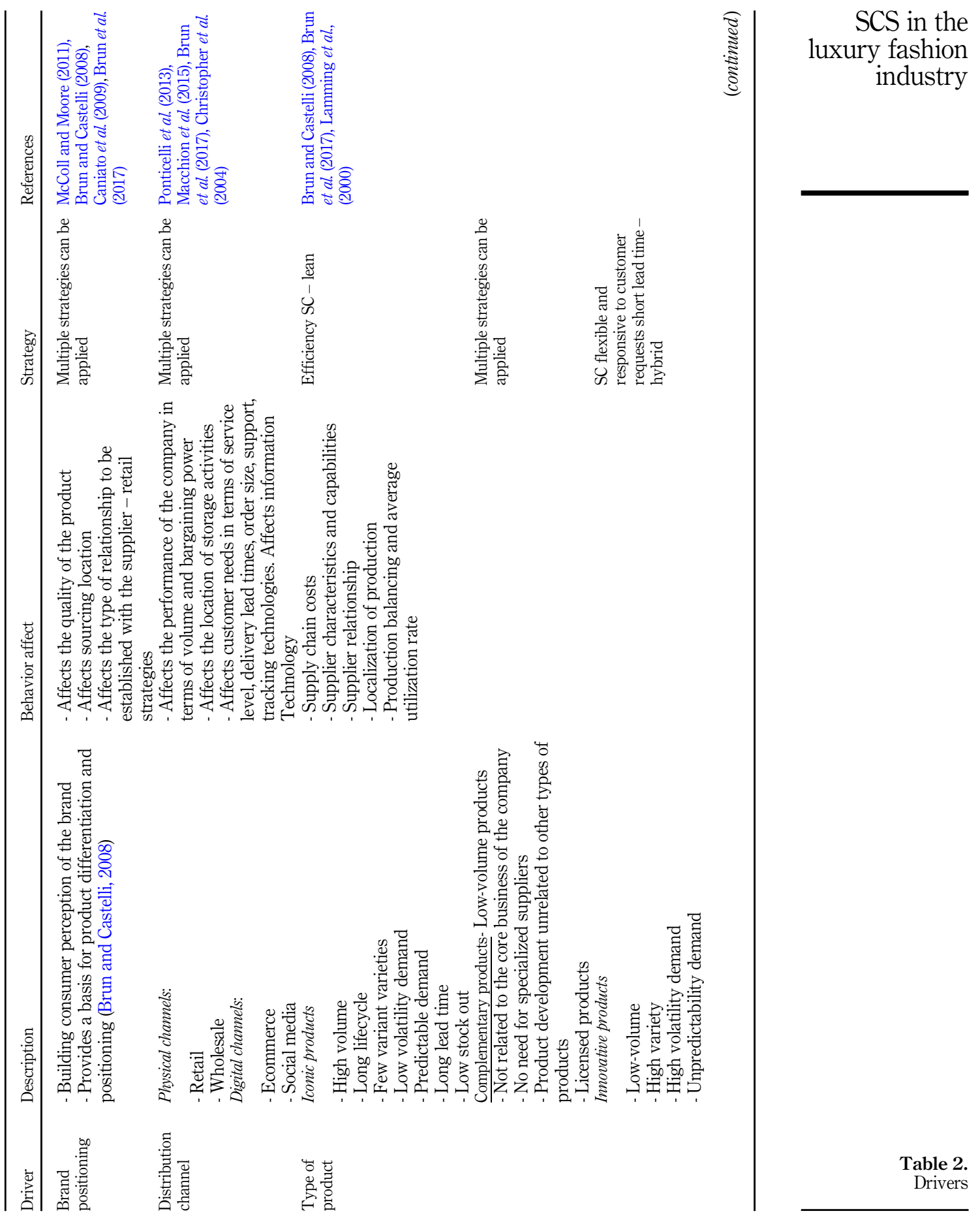

Table 2.

Drivers 


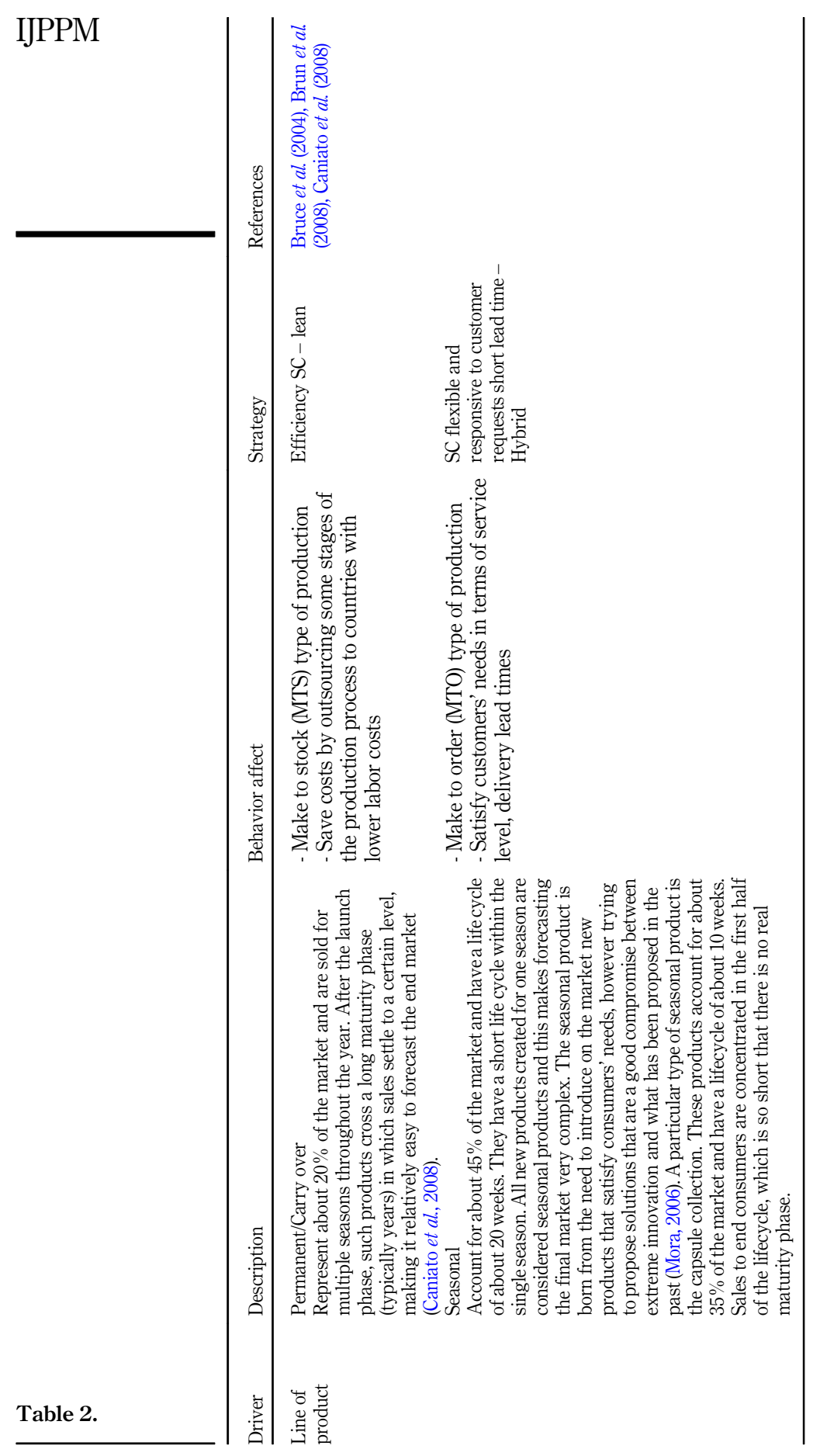


KPIs are used by the organizations in order to ensure that they are proceeding in correct direction, achieving targets in terms of organizational goals and objectives. The performance measures are used to evaluate and control the overall business operations. These indicators are also used to measure and compare the performance of different organizations within the industry, plants, departments, teams as well as between individuals, respectively (Ghalayini et al., 1997; Ishaq Bhatti and Awan, 2014; Parmenter, 2015).

Therefore, KPIs, beyond the objective of improving SC performance, may also represent the means to align the $\mathrm{SC}$ with the business strategy.

In order to identify the KPIs measured by fashion companies, a structured literature analysis was conducted (Figure 1).

From the analysis of the selected papers, an initial set of 33 KPIs was firstly identified starting from the following keywords: ("Key performance indicator" OR "performance measurement") AND (fashion OR luxury) and (SCOR AND fashion). These were both generic for manufacturing and specific for the fashion sector. The identified KPIs were then integrated and detailed through the metrics of the supply-chain operations reference (SCOR) model and design chain operations reference (DCOR) model. For example, the supplier service

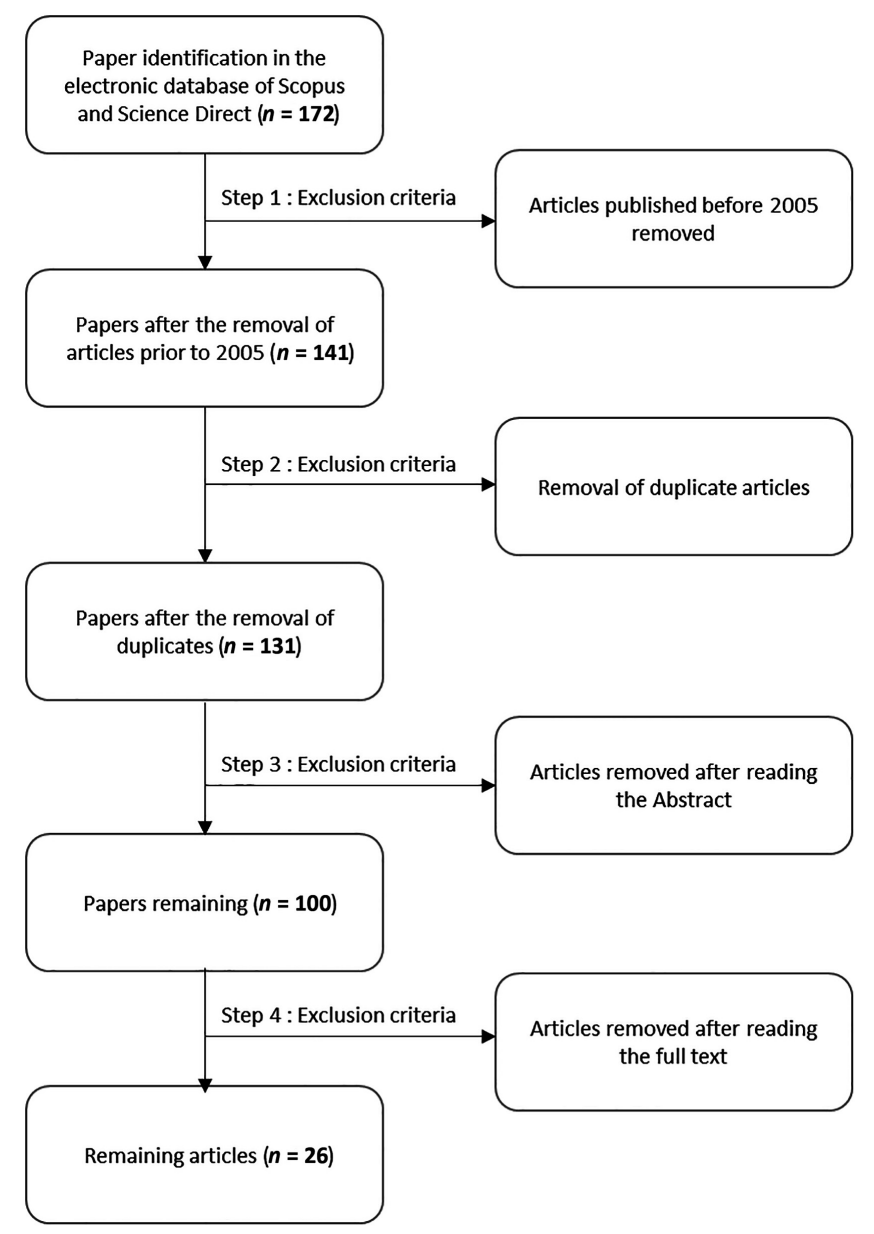

Figure 1 . Literature review strategy 
level was subdivided into three indicators identified in the SCOR model as follows: \% of orders received on time with respect to the requested date, $\%$ of orders received with the correct quantity requested and \% of compliant orders received. Thus, the number of KPIs identified in the literature as a result of the integration of the metrics present in the DCOR and SCOR models increases from 33 to 53. Finally, the number of identified KPIs increases again from 53 to 71 as a result of the previously detailed breakdown operation (Figure 2).

Subsequently, a further analysis to understand how to classify and categorize the identified KPIs was then conducted. The literature provides several examples of classification, but for the purpose of the present article, KPI classification was performed using the classification framework of the DCOR and SCOR models, respectively (Thilakarathna et al., 2015).

Following this classification, a second classification was performed according to the three types of SCS previously identified.

The classification of KPIs within a single strategy was made according to the order winner-qualifier matrix. Hill (1995) introduced the concept of order winner (OW) and order qualifier $(\mathrm{OQ})$ by contending that manufacturing companies should choose their strategy based on these parameters. The correct definition of the OQ and OW leads to a correct definition of the business strategy which, in turn, results in strategic choices at the SC level.

It' is essential to understand the connection between the concept of OW and OQ, and lean and agile strategies, respectively. For example, a lean strategy is more effective when the OW is the cost, whereas an agile SCS is more effective when the OW is the service level (MasonJones et al., 2000).

Starting from the $\mathrm{OW}$ and $\mathrm{OQ}$ matrix, it was possible to produce a second classification by positioning the KPIs within the identified strategies. The association between KPIs and SCS, identified from the literature analysis, was carried out using the OW concept, since it was chosen to report and classify only those KPIs related to the cost (OW of the Lean strategy) for the lean strategy and those related to the service level (OW of the agile strategy) for the agile strategy.

The results of the KPIs process classification and the association to a strategy are shown in Table 3.

During the case studies, the above classifications were used in order to verify whether the companies measure and monitor at least the set of identified KPIs, even if under a different name, necessary to achieve the objectives and implement a lean or agile SCS.

\section{Research methodology}

The methodology selected was case-based research since this was considered a more suitable approach in answering the type of RQs formulated. The case-based research was carried out

Figure 2.

KPI selection

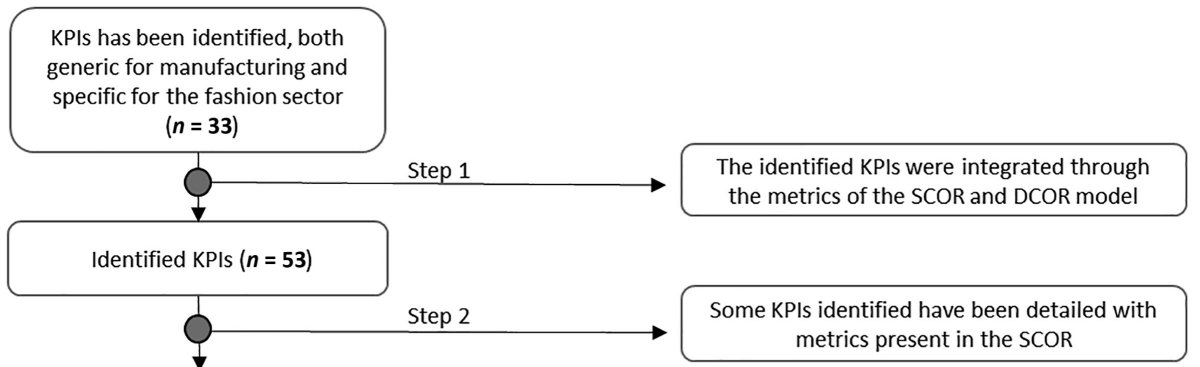

Total KPIs identified $(\boldsymbol{n}=\mathbf{7 1})$ 


\begin{tabular}{|c|c|c|c|c|}
\hline Process & KPI & References & $\begin{array}{l}\text { Strategy } \\
\text { OW }\end{array}$ & luxury fashion \\
\hline NPD & Development of prototype cycle time & $\begin{array}{l}\text { Yeh et al. (2010), Sherman et al. (2005), Dombrowski } \\
\text { et al. (2013), DCOR (design), }\end{array}$ & N/A & \\
\hline NPD & Total cost of prototypes realized & DCOR (design) & $\mathrm{L}$ & \\
\hline NPD & Total cost of samples produced & DCOR (design) & $\mathrm{L}$ & \\
\hline NPD & \# Of new models planned & DCOR (design) & $\mathrm{N} / \mathrm{A}$ & \\
\hline NPD & \# Of new products introduced & $\begin{array}{l}\text { Cai et al. (2009), Chan (2003), Shepherd and Günter } \\
\text { (2011), DCOR (integrate) }\end{array}$ & A & \\
\hline NPD & \# Of changes per product design & DCOR (design, integrate, Amend) & $\mathrm{A}$ & \\
\hline NPD & $\begin{array}{l}\text { Total cost of new product } \\
\text { development }\end{array}$ & $\begin{array}{l}\text { Pinna et al. (2017), Piotrowicz and Cuthbertson (2015), } \\
\text { Yeh et al. (2010) }\end{array}$ & $\mathrm{L}$ & \\
\hline NPD & $\begin{array}{l}\text { Average time associated with new } \\
\text { product changes }\end{array}$ & Sherman et al. (2005), Pinna et al. (2017) & N/A & \\
\hline $\mathrm{P}$ & Volatility of forecasts & Chae (2009) & L-A & \\
\hline $\mathrm{P}$ & Forecasting technique accuracy & $\begin{array}{l}\text { Bhagwat and Sharma (2007), Lapide (2000), Shepherd } \\
\text { and Günter (2011), Chae (2009), Papakiriakopoulos } \\
\text { and Pramatari (2010), Gunasekaran et al. (2004), } \\
\text { SCOR (RL 3.37) }\end{array}$ & L-A & \\
\hline $\mathrm{P}$ & Cost of supply chain management & $\begin{array}{l}\text { Cai et al. (2009), Chan (2003), Lapide (2000), Shepherd } \\
\text { and Günter (2011) }\end{array}$ & $\mathrm{L}$ & \\
\hline $\mathrm{S}$ & Supplier lead time & $\begin{array}{l}\text { Bhagwat and Sharma (2007), Gunasekaran et al. } \\
\text { (2004), Shepherd and Günter (2011) }\end{array}$ & N/A & \\
\hline $\mathrm{S}$ & $\begin{array}{l}\text { Supplier service level (product } \\
\text { compliance, quantity) }\end{array}$ & $\begin{array}{l}\text { Shepherd and Günter (2011), Bhagwat and Sharma } \\
\text { (2007), Gunasekaran et al. (2004), Chan (2003), Sellitto } \\
\text { et al. (2015) }\end{array}$ & $\mathrm{A}$ & \\
\hline $\mathrm{S}, \mathrm{D}$ & $\begin{array}{l}\text { Total cost of raw materials/semi- } \\
\text { finished products/finished warehouse } \\
\text { products }\end{array}$ & $\begin{array}{l}\text { Beamon (1999), Bhagwat and Sharma (2007), Cai et al. } \\
\text { (2009), Chan (2003), Otto and Kotzab (2003), Shepherd } \\
\text { and Günter (2011), Stewart (1995), Thilakarathna et } \\
\text { al. (2015) }\end{array}$ & $\mathrm{L}$ & \\
\hline S, D & Warehouse obsolescence costs & $\begin{array}{l}\text { Beamon (1999), Chae (2009), Shepherd and Günter } \\
\text { (2011) }\end{array}$ & $\mathrm{L}$ & \\
\hline $\mathrm{S}, \mathrm{D}$ & $\begin{array}{l}\text { Inventory level of raw materials/semi- } \\
\text { finished products/finished products }\end{array}$ & Sellitto et al. (2015) & $\mathrm{L}$ & \\
\hline $\mathrm{S}$ & $\begin{array}{l}\% \text { Of wrong deliveries (quantity, non- } \\
\text { conforming products) }\end{array}$ & $\begin{array}{l}\text { Bhagwat and Sharma (2007), Chan (2003), Shepherd } \\
\text { and Günter (2011), Thilakarathna et al. (2015) }\end{array}$ & $\mathrm{A}$ & \\
\hline $\mathrm{S}$ & Return cost & SCOR (CO.2.007) & $\mathrm{L}$ & \\
\hline $\mathrm{S}$ & $\begin{array}{l}\text { Identifying sources of supply cycle } \\
\text { time }\end{array}$ & SCOR (RS.3.35) & N/A & \\
\hline $\mathrm{S}$ & $\begin{array}{l}\text { Select supplier and negotiate cycle } \\
\text { time }\end{array}$ & SCOR (RS.3.125) & N/A & \\
\hline $\mathrm{S}$ & Verify product cycle time & SCOR (RS.3.140) & $\mathrm{N} / \mathrm{A}$ & \\
\hline $\mathrm{S}$ & $\begin{array}{l}\text { Material landed cost } \\
\text { - Cost of purchased materials } \\
\text { - Material transport cost } \\
\text { - Customs material cost, duties, } \\
\text { taxes and tariffs }\end{array}$ & SCOR (CO.2.003) & $\mathrm{L}$ & \\
\hline $\mathrm{S}$ & Defective inventory percentage & SCOR (AM.3.28) & $\mathrm{A}$ & \\
\hline $\mathrm{S}$ & Delivery item accuracy & SCOR (RL.3.33) & $\mathrm{A}$ & \\
\hline $\mathrm{S}$ & Delivery quantity accuracy & SCOR (RL 3.35) & $\mathrm{A}$ & \\
\hline $\mathrm{S}$ & $\begin{array}{l}\% \text { orders received on time to demand } \\
\text { requirement }\end{array}$ & SCOR (RL 3.20) & A & \\
\hline M & Total production costs & Beamon (1999), Cai et al. (2009), Shepherd and Günter & $\mathrm{L}$ & \\
\hline & $\begin{array}{l}\text { - Production labor costs (direct) } \\
\text { - Cost of automation } \\
\text { - Cost of productive assets } \\
\text { - Production management costs }\end{array}$ & , SCUK (CO.Z.004) & (continued) & $\begin{array}{r}\text { Table } 3 . \\
\text { KPI classification }\end{array}$ \\
\hline
\end{tabular}




\begin{tabular}{|c|c|c|c|}
\hline Process & KPI & References & $\begin{array}{l}\text { Strategy } \\
\text { OW }\end{array}$ \\
\hline M & Production lead time & $\begin{array}{l}\text { Beamon (1999), Chan (2003), Shepherd and Günter } \\
\text { (2011), Thilakarathna et al. (2015) }\end{array}$ & N/A \\
\hline M & \# Stock keeping unit (SKU) & $\begin{array}{l}\text { Shepherd and Günter (2011), Gunasekaran et al. } \\
\text { (2004), Bhagwat and Sharma (2007) }\end{array}$ & N/A \\
\hline M & Productivity & $\begin{array}{l}\text { Gunasekaran et al. (2004), Kumar Hurreeram et al. } \\
\text { (2014) }\end{array}$ & $\mathrm{L}$ \\
\hline M & Production capacity & $\begin{array}{l}\text { Bhagwat and Sharma (2007), Gunasekaran et al. } \\
\text { (2004), Otto and Kotzab (2003), Kumar (2013), Kumar } \\
\text { Hurreeram et al. (2014) }\end{array}$ & $\mathrm{L}$ \\
\hline M & $\%$ of non-compliance on total products & $\begin{array}{l}\text { Gunasekaran et al. (2004), Sellitto et al. (2015), Kumar } \\
\text { Hurreeram et al. (2014) }\end{array}$ & A \\
\hline M & Make cycle time & Yeh et al. (2010), Pinna et al. (2017), SCOR (RS.2.2) & N/A \\
\hline $\mathrm{D}$ & Inventory turnover & $\begin{array}{l}\text { Lapide (2000), Shepherd and Günter (2011), Otto and } \\
\text { Kotzab (2003), Battista and Schiraldi (2013), } \\
\text { Papakiriakopoulos and Pramatari (2010) }\end{array}$ & N/A \\
\hline $\mathrm{D}$ & Transportation costs & $\begin{array}{l}\text { Beamon (1999), Cai et al. (2009), Chan (2003), } \\
\text { Gunasekaran et al. (2004), Kumar Hurreeram et al. } \\
\text { (2014), Otto and Kotzab (2003), Shepherd and Günter } \\
\text { (2011), Thilakarathna et al. (2015), SCOR (CO.3.022) }\end{array}$ & $\mathrm{L}$ \\
\hline $\mathrm{D}$ & Customer response time (service level) & $\begin{array}{l}\text { Beamon (1999), Bhagwat and Sharma (2007), Cai et al. } \\
\text { (2009), Chan (2003), De Felice and Petrillo (2013), } \\
\text { Gunasekaran et al. (2004), Lapide (2000), Otto and } \\
\text { Kotzab (2003), Sellitto et al. (2015), Shepherd and } \\
\text { Günter (2011) }\end{array}$ & A \\
\hline $\mathrm{D}$ & \# of on-time deliveries & $\begin{array}{l}\text { Beamon (1999), Chae (2009), Chan (2003), De Felice } \\
\text { and Petrillo (2013), Lapide (2000), Sellitto et al. (2015), } \\
\text { Shepherd and Günter (2011), Thilakarathna et al. } \\
\text { (2015) }\end{array}$ & A \\
\hline $\mathrm{D}$ & Distribution Lead time & $\begin{array}{l}\text { Shepherd and Günter (2011), Gunasekaran et al. } \\
\text { (2004) }\end{array}$ & N/A \\
\hline $\mathrm{D}$ & $\%$ of urgent deliveries & $\begin{array}{l}\text { Gunasekaran et al. (2004), Bhagwat and Sharma } \\
\text { (2007) }\end{array}$ & A \\
\hline $\mathrm{D}$ & \# stock out & $\begin{array}{l}\text { Beamon (1999), Cai et al. (2009), Chan (2003), Otto and } \\
\text { Kotzab (2003), Shepherd and Günter (2011), } \\
\text { Thilakarathna et al. (2015) }\end{array}$ & $\mathrm{L}$ \\
\hline $\mathrm{D}$ & \# back order & $\begin{array}{l}\text { Beamon (1999), Shepherd and Günter (2011), } \\
\text { Thilakarathna et al. (2015) }\end{array}$ & $\mathrm{L}$ \\
\hline $\mathrm{D}$ & \# lost sales & Mattila et al. (2002) & $\mathrm{L}$ \\
\hline $\mathrm{D}$ & Sell-thought (\%) & $\begin{array}{l}\text { Beamon (1999), Cai et al. (2009), Mattila et al. (2002), } \\
\text { Moore and Fairhurst (2003), Shepherd and Günter } \\
\text { (2011) }\end{array}$ & $\mathrm{L}$ \\
\hline $\mathrm{D}$ & New product sales rate & Cai et al. (2009) & A \\
\hline $\mathrm{D}$ & $\%$ of orders delivered in full (quantity) & Beamon (1999), SCOR (RL 2.1) & A \\
\hline $\mathrm{D}$ & $\begin{array}{l}\% \text { defect free conformance orders } \\
\text { delivered }\end{array}$ & SCOR (RL 3.42) & A \\
\hline $\mathrm{R}$ & $\begin{array}{l}\% \text { of products replaced (non- } \\
\text { compliant) }\end{array}$ & $\begin{array}{l}\text { Mattila et al. (2002), Sellitto et al. (2015), Kumar } \\
\text { Hurreeram et al. (2014) }\end{array}$ & A \\
\hline
\end{tabular}

Table 3.

Note(s): NPD: new product development; P: plan; S: source; M: make; D: delivery; R: return; L: lean; A: agile; N/A: not applicable

in the first phase and included the analysis of secondary sources and interviews carried out in all the companies. These interviews were conducted using a questionnaire.

The methodology was organized into two steps. The first step was the selection of a sample of luxury fashion companies (Eisenhardt, 1989; Maimbo and Pervan, 2005). Multiplecase sampling was used to increase confidence in the findings (Miles and Huberman, 1984) 
and support their external validity. The research involved selecting a sample of six companies, belonging to the luxury fashion industry, with different sizes and turnovers that were representative of most of the companies in this sector. Of the six sample companies selected, there were two international brands belonging to leading groups in the luxury fashion sector, one smaller company with a strong vocation for craftsmanship and exclusivity, and three brands with smaller turnover and company size. According to Eisenhardt (1989) selecting a sample size ranging between four and ten cases is effective in this type of research approach. Hence, a sample size of six was considered sufficient in providing an accurate representation in an empirical based research. The sample was composed of companies with heterogeneous characteristics regarding the drivers that potentially influence the choice of SCS identified in the literature. In particular, the selected companies were also represented by some common drivers, thereby permitting us to compare the strategies and KPIs implemented by these companies. Additionally, the companies were also represented by different drivers, thereby highlighting all the differences and permitting us to cover all the distinctive features of the sector.

Then in the data collection phase, all the information in answer to the RQ was obtained. In the first phase, a semi-structured two-hour interview was conducted. Initially, information was collected from indirect sources and from previous knowledge given by projects carried out within the company, and thereafter, included the SC and Information Manager (IM) of the companies identified within the sample. The interviews were carried out using a questionnaire (i.e. consisting of a first part of open-ended questions and a second part of closed-ended questions) divided into three sections. In the first section, general information about the companies was gathered. Then, the second section was dedicated to obtaining information about the drivers (i.e. distribution channel, type of product and line of product) that could be influenced by the choice of SCS. In turn, the third section was aimed at discovering the KPIs monitored, controlled and/or optimized by the luxury fashion companies examined. Finally, both the main characteristics of the individual companies and any points of contrast or similarity between all the companies in the sample were identified in the analysis and synthesis phases, respectively. In the data analysis phase, a transcription and reworking of the information obtained by each individual interviewed within the company was carried out in order to compare all the answers obtained. The realization of these documents was necessary in order to be able to make a representative report of each case study, and then to compare the case studies through a cross-case analysis.

In Table 4 the individual luxury fashion firms involved in the present case study were presented.

A brief summary of the companies is presented below.

Company 1 forms part of the luxury fashion industry, founded in Spain in the 1900s. Last year alone, the company invoiced about $239 \mathrm{M} €$. Currently, this company is experiencing a period of strong growth and as a result is planning to be autonomous from the owner group, particularly in the footwear sector.

Company 2 is one of the most important luxury fashion companies both in Italy and worldwide. This company was founded in the early 1900 s with an increasing turnover $(1 \mathrm{~B} €$ in 2019). It manages multiple product lines, including handbags, small leather goods, footwear, ready to wear, bijoux, fashion accessories, furs, belts and fashion jewels.

Company 3 was founded in Milan and is focused on leather goods (bags and accessories). The turnover, according to the latest available data, is approximately $3.2 \mathrm{~B} €$. This company manages many lines, including ready to wear, footwear, leather goods, bijoux, accessories, bags, belts, jewels, perfumes and cosmetics.

Company 4 was founded in Florence in the second half of the 1900s. Originally a small family-run luxury fashion boutique, specialized in the creation of ties, it has currently expanded to become an important international luxury group pillar of made in Italy haute
SCS in the
luxury fashion
industry

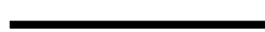




\begin{tabular}{|c|c|c|c|c|c|c|c|c|}
\hline \multirow[t]{2}{*}{ IJPPM } & Company & country & $\begin{array}{l}\text { No. of } \\
\text { lines }\end{array}$ & Main product & $\begin{array}{l}\text { Age of the } \\
\text { company } \\
\text { (years) }\end{array}$ & Turnover & $\begin{array}{l}\text { No. of } \\
\text { SKU }\end{array}$ & $\begin{array}{l}\text { Roles of the } \\
\text { people } \\
\text { interviewed }\end{array}$ \\
\hline & 1 & Spain & 4 & $\begin{array}{l}\text { Footwear } \\
\text { Leather goods } \\
\text { - bags }\end{array}$ & 60 & 239,2 M€ & \multirow[t]{2}{*}{$\begin{array}{l}500 \\
<\# \\
\text { SKU }< \\
1,000 \\
>1,000\end{array}$} & $\mathrm{SC}$ manager \\
\hline & 2 & Italy & 10 & $\begin{array}{l}\text { Footwear } \\
\text { Leather goods } \\
\text { - bags }\end{array}$ & 90 & $1 \mathrm{~B} €$ & & $\begin{array}{l}\text { SC manager, IT } \\
\text { manager }\end{array}$ \\
\hline & 3 & Italy & 7 & $\begin{array}{l}\text { Leather goods } \\
\text { - bags }\end{array}$ & $>100$ & $3.2 \mathrm{~B} €$ & $>1,000$ & $\mathrm{SC}$ manager \\
\hline & 4 & Italy & 25 & $\begin{array}{l}\text { RTW } \\
\text {-tailored } \\
\text { clothing for } \\
\text { men }\end{array}$ & 41 & $91,8 \mathrm{M} €$ & $\begin{array}{l}500 \\
<\# \\
\text { SKU }< \\
1,000\end{array}$ & $\begin{array}{l}\text { SC manager, IT } \\
\text { manager }\end{array}$ \\
\hline & 5 & French & 1 & Footwear & 30 & $1 \mathrm{~B} €$ & $\begin{array}{l}500 \\
<\# \\
\text { SKU }< \\
1,000\end{array}$ & $\mathrm{SC}$ manager \\
\hline $\begin{array}{l}\text { Table } 4 . \\
\text { Sample }\end{array}$ & 6 & England & 15 & $\begin{array}{l}\text { RTW } \\
\text { Leather goods } \\
\text { - bags }\end{array}$ & $>100$ & $2.7 \mathrm{B£}$ & $>1,000$ & $\begin{array}{l}\text { SC manager, IT } \\
\text { manager }\end{array}$ \\
\hline
\end{tabular}

couture with about 600 employees worldwide. The specialized production area is the "total look for men" (suits, shirts, jeans, polo shirts, casual wear and ties), which comprises completely hand-made items.

Company 5 was founded in France about 25 years ago and is positioned within the luxury fashion sector of women's footwear. The core business is represented by women's footwear, which has permitted the brand to attain a turnover of $1 \mathrm{~B} €$.

Company 6 originated in 1856 in Hampshire. The iconic items of the English luxury fashion houses are yarns, scarves, shawls and trench coats. The turnover (year 2017) was $2.8 \mathrm{~B} £$ with more than 10 thousand employees (in February 2018) and a capitalization of 7 million pounds (in April 2018).

For every single company, different case studies have been carried out, according to the specific product types realized by the companies. In total, 20 different case studies have been analyzed.

\section{1 "Within case" analysis of the SCS - RQ1}

In this section the results of the RQ1 were analyzed. In particular, the results of each case study are reported in Table 5.

Company 1 represented the high market segment of the luxury fashion industry. Regarding the second driver, distribution and sales channels, this company used both the wholesale channel (about 40\%), as well as the retail and commerce channels (about 60\%). The core business of the company is footwear and leather goods that are managed internally. Within this company, four different case studies have been carried out, according to the combination of different product types and product lines realized by the company. According to this, for each type of product there are different lines: carry over and seasonal. The carry over products represent $30 \%$ of the total products while the remaining $70 \%$ is composed of seasonal products. The raw materials (RM) are managed in stock and are, therefore, purchased in advance (before the arrival of the orders). For the carry over, the management of 


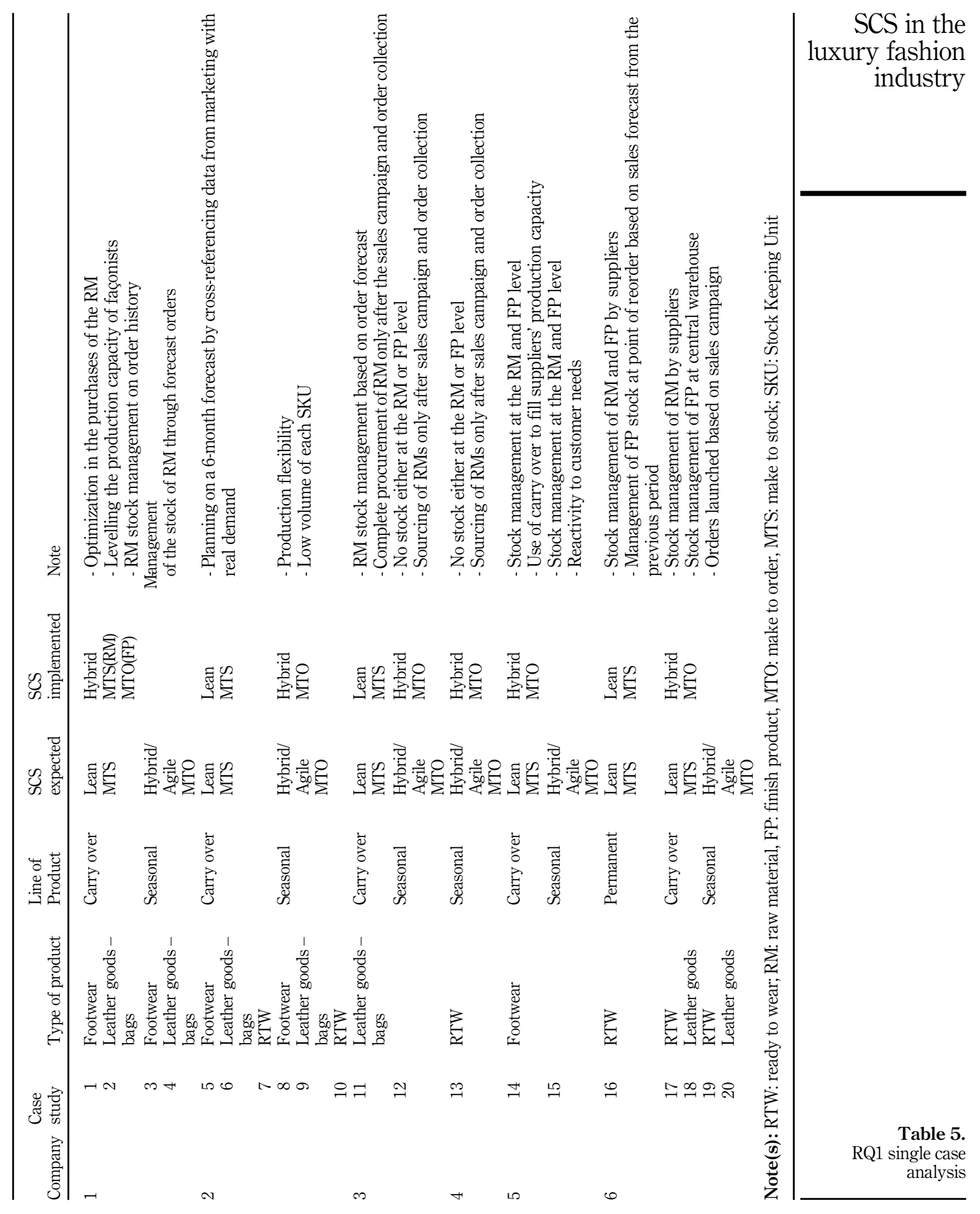


the RM stock is based on the order history, while for the seasonal products RM stock management is attained from "blind orders" through sales forecasts. At the finished product (FP) level, carry over, seasonal products are managed through an MTO type of production. In particular, the decoupling point is positioned in the warehouse of the RM.

To summarize the results related to the drivers identified in the literature that influence the choice of the SCS, it can be seen that the company 1 belongs to the luxury fashion market segment, that employs the use of the retail channel $(60 \%)$ as the preferential sales channel. Finally, the core business is made up of two types of product, and each comprises two product lines, respectively. The results of case studies 1 and 2 show a misalignment with the strategies that are expected (based on the literature analysis) at FP level. In particular for these case studies, company 1 implemented a hybrid SCS with an MTO type of production instead of a lean SCS with an MTS type of production. Instead, for the case study 3 and 4 company 1 implements an SCS in harmony with those suggested and expected by the literature.

Company 2 was also shown to manage many product typologies; however, the core business is in leather goods, shoes and ready to wear (RTW). The sales channels used by the company are both retail and wholesale. For leather goods (bags) approximately $70 \%$ is sold through the retail channel and the remaining $30 \%$ through the wholesale channel, respectively. For the footwear, 60 and $40 \%$ are sold through the retail and wholesale channels, respectively. The company 2 deals with both carryover products (about $20 \%$ for shoes and $40 \%$ for bags) as well as seasonal products. Within the company 2 , carry over product planning is accomplished through a sales forecast with a time horizon spanning six months on the basis of data derived from marketing. These data are then cross-referenced with real demand. For case studies 5, 6 and 7 all the types of product and carry over lines are obtained according to an MTS type of production, while for the case studies 8, 9 and 10 all the type of products and in particular for seasonal lines are managed according to an MTO type of production.

Summing up, company 2 uses the retail channel $(60 \%)$ as a preferential distribution channel. Unlike company 1, for company 2 there was a complete alignment with the strategies expected downstream the literature analysis for all the case studies conducted.

The results reported for Company 3 and 4 are similar to those of Company 2. Both companies produce the same type of products and implement for all the case studies 11, 12 and 13 an SCS in harmony with those suggested and expected by the literature.

Company 5 represents an icon for luxury fashion women's footwear. As far as sales channels are concerned, the company owns 126 mono brand shops located all over the world. The ecommerce channel still has rather limited sales volume and is not exploited by the company compared to the more classic retail channel, which is comprises $60 \%$ of total sales. For the case studies 14 and 15 and in particular for footwear, both the carry over and seasonal lines are managed by a hybrid SCS and an MTO type of production. Overall, $80 \%$ of the collection comprises seasonal products, with the remaining $20 \%$, composed of carry over products. From the data, it is evident that this company is focused on the development of new products to meet the needs of the customers for each season.

To sum up, company 5 belongs to the luxury fashion market segment that uses the retail channel as the preferred SCS channel $(60 \%)$. It is possible to highlight a misalignment for the case study 14 since for footwear type of product and carry over product line, company 5 implements a Hybrid strategy through an MTO type of production contrary to what the literature suggests. On contrary, it is possible to find an alignment for the case study 15 with the SCS suggested by the literature in particular for footwear product type and seasonal line, company 5 implemented a Hybrid SCS with an MTO type of production.

Finally, company 6 is a world-renowned brand operating in the luxury fashion sector. The core business of the company is represented by men's and women's clothing, comprising $70 \%$ of the turnover, with the remaining $30 \%$ relegated to accessories, particularly leather goods, which have been expanding in recent years. The distribution channels used by the company 6 
are both retail and wholesale, respectively, comprising $45 \%$ of the sales volumes. In company 6 , five different case studies have been conducted (from 16 to 20 ) for the three different types of products managed by the company. These include permanent products, such as the traditional trench coat, waterproof coats and various bags and scarves, which have a long-life cycle. In addition, there are the carry over products with a life-span of least one year and finally, the seasonal products that are designed to respond to the customers' needs. A total of 40 and $60 \%$ of the collection are composed of carry over products and seasonal products, respectively. The company produces all products externally, ordering finished items directly from the suppliers. For the permanent products, the supplier's stock both RM and FP as sales forecasts for these products have a time span of two years. Also, seasonal products are made by suppliers who exercise freedom to purchase RM. In case study 17 and 18 for both product types and carry over line are made with an MTO type of production. No stock is produced because in case the products remain unsold, the supplier is directly responsible for the goods left in the warehouse.

As before, the company 6 uses the retail channel as the preferred SCS channel $(80 \%)$.

For the case study 16, there is total alignment with the strategies expected after the literature analysis. In particular, it is possible to highlight how a lean strategy was implemented for products that are permanent fixtures on the market. In case study 17 and case study 18 considering different type of product (RTW and leather goods) but the same line of product (Carry Over), for both case, there was a misalignment with the literature. For these cases, a Hybrid strategy was implemented instead of a lean strategy suggested by the literature, as for the seasonal products (case studies 19 and 20), because if left unsold, the supplier is responsible for the goods remaining in stock.

\section{2 "Cross case" analysis of the SCS - RQ1}

In order to carry out this analysis a "clustering" of the sample was made. The clustering was obtained distinguishing between companies that produce leather goods (bags) and footwear with leather as the RM and companies that produce the RTW as the principle product. This type of cluster was created because the SC of leather goods and footwear are very similar, characterized by a network of local suppliers and production planning that are connected to leather as the main RM. Instead, the SC of RTW is very different because is much more extensive and has a production planning that is linked to all components and not only to the availability of the principle RM.

As can be seen in Table 6, for both types of clusters identified, the only product line not aligned with the expected SCS is the carry over (case study 2, 14, 17, 18). Instead, the seasonal line was always shown to be aligned with the expected SCS, regardless of the type of product being produced. It is possible to conclude that the only driver that affects the alignment between the expected and implemented SCS, respectively, is the product line.

It can be noticed that carry over products are managed by most companies using a hybrid strategy and MTO type of production. The reasons why the companies examined opted for such strategy are attributable to the following factors:

(1) "The forecast of the demand of carry over products is affected by high error" as mentioned by the SC manager of the company 1 for the case studies \#1 and \#2. In

\begin{tabular}{lcccr}
\hline & \multicolumn{2}{c}{ Carry over } & \multicolumn{2}{c}{ Seasonal } \\
Cluster & Aligned & Not aligned & Aligned & Not aligned \\
\hline RTW & 7,16 & $\mathbf{1 7}$ & $10,13,19$ & \\
Bag and footwear & $1,2,5,6,11$ & $\mathbf{2 , 1 4 , 1 8}$ & $3,4,8,9,12,15,20$ & \\
\hline
\end{tabular}

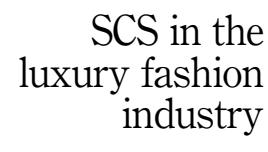

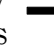


fact, the accuracy of the predictions is affected by the number of years the product remains on the market. For this reason, it is feasible to make reliable predictions when dealing with iconic and stable products that remain on the market for many years. This scenario is very different for seasonal products that become carry overs from one season to the next. Market predictions for these carry over products have duration equal to one year. The high value of the RM (especially fine leathers or accessories) necessitates that companies store such RM inside warehouses that have high purchase and management costs.

(2) Also, the SC manager of the case study \#5 and \#14 for footwear type of product said that "There are difficulties in managing sizes when it comes to clothing or footwear products".

(3) For the case studies \# 1, \# 2, \# 3, \# 4, \#14 and \#15 there is also increased complexity in the simultaneous management of different types of productions according to the product category (carry over, seasonal and capsules)

(4) Moreover, both the SC and IT manager of the case studies \# 5, \# 6, \# 7, \# 17 and \# 18 said that "To pursue the saturation of the façonists, companies are ordering the production of carry over".

\section{3 "Within case" analysis of the KPIs - RQ2}

Among the KPIs selected in the literature, the main performance parameters measured by the companies were identified. In a second step, the alignment between the KPIs actually measured by the six companies comprising the case studies and those identified in from literature classification of KPIs within a single strategy were verified.

Below, in Table 7, the results that emerged from the individual case studies carried out are reported:

From the results of the single case analysis it was found that depending on the product line of the brand, it was possible to identify different approaches to KPIs measurement.

3.3.1 Carry over products. For all companies implementing this product line, regardless of the SCS implemented, there was a partial alignment with the cost KPIs characteristic of a lean strategy, expected after the classification realized and the indicators measured by companies. Within the design phase, the companies measure only one cost KPI among those identified. This aspect was justified by the number of years the product has been on the market. Therefore, for a structured product, subject to only occasional changes, it is less important to monitor KPIs related to the prototyping and engineering phase. These indicators were measured only in the first year, following the introduction of the product, and possibly in the following years, when the product was classified as seasonal. As far as the plan phase was concerned, the companies in the sample only measure the indicator related to the "total supply chain cost". For this type of product, the demand is more stable and therefore indicators such as "accuracy of forecasts" and "volatility of forecasts" are not subject to continuous monitoring and measurements.

There was a complete alignment with the source, make, delivery and return phases and the cost KPIs characteristic of a lean strategy expected after the classification realized and the indicators measured by companies. An aspect that emerges from the source and production phases is that the attention of some of the companies is addressed, not only to the monitoring of costs, but also to the quality of the RM and the product produced. This aspect is confirmed from the luxury fashion brands examined, indicating that the companies view both the quality of the RM and FP as an essential value for the product produced. In these aforementioned phases of the process, companies monitor lead time indicators. This is because the company implements continuous process improvement techniques in order to 


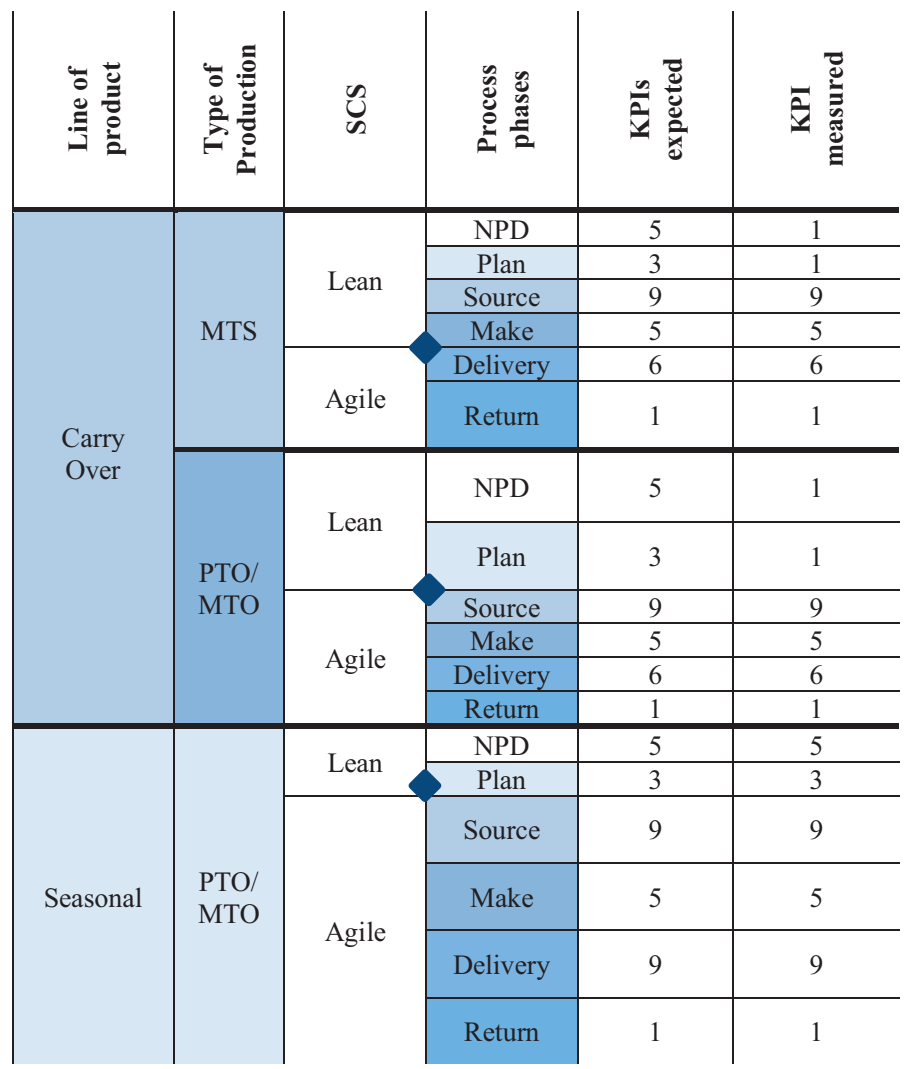

Note(s): NPD: New Product Development; DP: Decoupling Point

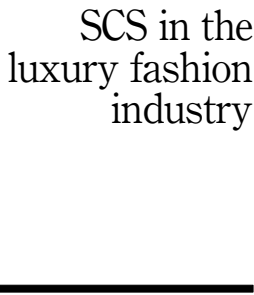

Table 7.

Results of RQ2 single case analysis

streamline the life cycle and reduce the product throughout time. Specifically, the parameters related to quality ( $\%$ compliant orders received) and lead time $(\%$ of orders received on time compared to the requested date, $\%$ of orders received with the correct quantity requested, $\%$ orders with change in delivery date, \# order change requests satisfied, \# accessible information/\# total information) are monitored and reported by companies, in addition to the cost KPIs for the source and make phases.

3.3.2 Seasonal products. For seasonal and capsule products, the KPIs are fully aligned with the cost indicators characteristic of a lean strategy, as could be expected from the classification of KPIs obtained from the literature those indicators measured by companies. For this type of product, all the KPIs of new product development (NPD) are measured and considered very important by the companies. This is attributable to the fact that the costs related to the development and the industrialization of new prototypes have a significant impact on the total cost of the collection.

Within the plan phase, the companies in the sample study measure all the KPIs very carefully because the demand for these products is both uncertain and difficult to predict. Within this phase, some purchase orders of "critical" RMs or production orders are made in advance, especially in the case of commercialized products. The reason why these orders are 
made is twofold. This is related to the limited availability of some RMs and the high supply lead time, often not compatible with the market demands.

For the source phase, the sample companies monitored all the KPIs related to the service level present in the set of indicators characteristic of an agile strategy identified from the literature analysis. In particular, among the service level KPIs measured, are those pertaining to the capacity of the supplier to change both the delivery date and the quantity ordered, after the first issue of the order by the brand. For some of the companies in the case study, the supplier's ability to meet the requirements for small batches of materials and to be willing to work with the brand in order to develop new products is critical. It is important to emphasize that KPIs related to the service level are influenced by parameters such as lead time and quality (OQ for an agile SCS) in both the source and make phases. Companies are often compelled to change their production planning either because of delays in delivery times or because of non-conformity relating to the RM. In the case in which the suppliers of RM (like leather or precious materials) deliver a material with high lead supply time and with nonconformities, the combination of these two parameters could impact both on production time and, as a result, on the service level.

In the source phase, some companies also monitor KPIs relating to costs including the total cost of the RM, warehouse and obsolescence. In particular, companies also monitor the cost of the RM that they purchase from additional suppliers. This serves to always guarantee the availability of RM and to obtain better prices, attributable to the competition between the various supply companies.

The KPIs monitored in the production phase by the companies include "production efficiency", but also the " $\%$ of non-conformity on the total product", the " $\%$ of available capacity" (both internally and at the façonists) and the " $\%$ of orders with delivery date variation during the production lead time".

Having to guarantee a high quality of the FP, "production efficiency" is a particularly important KPI, and is monitored by the company. This KPI is translated in specific measures related to the quality of the FP but also on the capacity of the suppliers.

With regard to the service level KPIs, similar to that of the sourcing phase, companies monitor the "ability to adapt to the variation in demand" both in terms of priority on orders and in terms of quantities ordered by suppliers. In the luxury fashion sector, the ability to correctly predict demand is a fundamental requirement for all types of products, especially when the production of seasonal products is fundamental. For seasonal products, it is very important to monitor the capacity of suppliers in order to guarantee the same service level in the event that delivery dates and quantities are subject to variation. These variations are due to the continuous alignment between the sales predictions and the purchased orders.

For the delivery and return phases, managed in an agile mode by all six companies, the main indicators included the " $\%$ shipments managed on time compared to the customer's request", the "\% compliant orders processed" and the "average time associated with the receipt of a product to the store". The principle KPIs measured in the retail phase are closely linked to the preferred sales channel implemented by the company. All six companies in the sample study employed the retail channel as the predominant channel. As a consequence, attention was primarily focused on the performance of the stores, and in particular on the KPIs such as the success rate of new products, coined by the phrases "Sell In", "Sell Out" and "Sell Through".

\section{4 "Cross case" analysis of KPIs - RQ2}

Following the single case analysis, a cross case analysis of the companies was then carried out.

To perform this analysis, we used the same clusters proposed in the cross-case analysis for DR1. In order to verify the alignment of the companies with the KPIs expected by the literature analysis, the percentage of indicators measured by each company with respect to 
the total KPIs proposed was calculated. The analysis was carried out for each company and for each type and product line produced by the respective company. In particular, the first step was to verify the alignment between the KPIs measured by the companies, for each product line, and the expected KPIs identified in the classifications obtained from the literature analysis. There was a total alignment $(100 \%)$ of the KPIs for the seasonal product line and capsule products for both Cluster 1(composed by the companies producing bags and footwear) and Cluster 2 (composed by all the companies that producing RTW) For the carry over product line, a partial alignment of $76 \%$ was found compared to the KPIs presented in the literature analysis (see Figure 3).

Subsequently, a second analysis was carried out, in each cluster, for the carry over product line (for which a partial alignment was found). The percentage of indicators monitored for each phase of the process was then calculated. The first phase of the process examined was the new product development. It was shown that all companies producing the carry over product line, for both clusters, measured only one indicator compared to the five indicators identified for this phase in the literature analysis. This was suggested to have contributed to $8 \%$ of the misalignment. The second phase of the process examined was the plan phase. The analysis showed that even within this phase the companies of both clusters measured a lower number of KPIs than those presented within literature analysis. Both clusters for the carry over product line were shown to have measured only one KPI of the three proposed indicators. In turn, this would have contributed to $16 \%$ of the misalignment. Hence, the results showed the misalignments reported were attributed only to these two phases within the process, given that the remaining phases were completely aligned with all the KPIs proposed by the literature analysis.

\section{Discussion}

The results allow us to provide an answer to the two research questions posed and to discuss the results against the literature. We focus our analysis on the differences between carry over, seasonal and capsule collection because this product line classification is widely used also in practice, thus creating a bridge among academic research and the industry.

As far as RQ1 is concerned, results suggest that there is a misalignment between what literature suggests and what companies implement for the carry over products, while literature is confirmed for seasonal product. In particular, although the literature suggests a lean strategy for carry over products (Brun et al., 2008), this strategy is not always followed

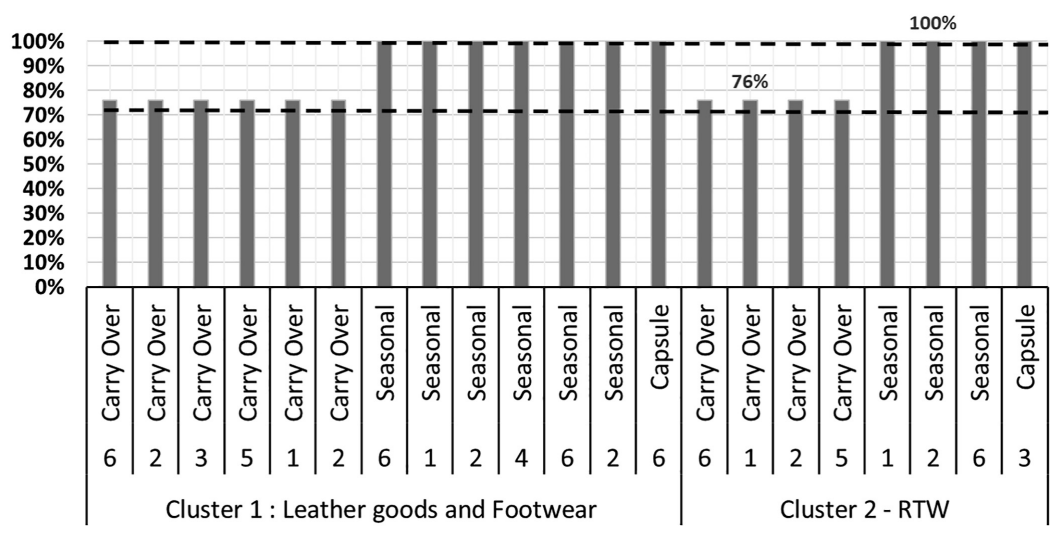

Figure 3. Results of RQ2 cross case analysis 
by companies. Carry over products are managed by most companies using a hybrid strategy, differently from what is suggested by the literature, i.e. lean (Bruce et al., 2004).

The analysis of the reasons why the companies examined opted for such strategies allow us to provide some contributions to the literature in the field.

First of all, the demand of carry over products is not always easy to forecast, differently from what the literature (Caniato et al., 2008) suggests. Indeed, the accuracy of the predictions is affected by the number of years the product remains on the market. For this reason, it is feasible to make reliable predictions when dealing with products that remain on the market for many years, i.e. those called permanent (Rigaud-Lacresse and Pini, 2017). This is not the case of those seasonal products that become carry over, for which therefore demand forecast is based on limited sets of data. Moreover, forecast accuracy is affected by the number of different sizes to forecast, and they can be an issue when it comes to clothing or footwear products.

Secondly, literature is suggesting a different SCS for each product family (Brun and Castelli, 2008). However, companies are managing portfolio of product families. So, to reduce the complexity in the simultaneous management of different types of SCS according to the line of product, they tend to not apply the SCS in its pure form. This might result in a reduction in the efficiency of the management of each product line, but in an increase in the global efficiency. This is the case, for instance, of the use of carry over as products to fill the production capacity of the façonists to compensate the low volumes of production of new products, which is strongly seasonal.

As far as RQ2 is concerned, the KPIs monitored confirm the suggestion by literature for any product line, but for carry over for the KPIs for NPD and plan process. This misalignment with the literature can be due to the nature of the product produced. The carry over line is by definition a product line that is sold season after season until market demand runs out (Caniato et al., 2008). For this reason, NPD indicators are occasionally measured on sample products. In addition, the planning phase of this product line is carried out on the basis of the average sales trend of previous seasons given that the product has been on the market for several years. Indicators such as uncertainty and volatility of demand do not need to be constantly monitored as unsold products can be left in stock and disposed of in the sales of the following season.

These results can be used to build a decision-making tool that build upon literature (e.g. Brun and Castelli, 2008) to propose companies a tool for selecting the SCS and the KPIs to monitor its deployment. First, the company defines the specific theoretical SCS for each combination of brand positioning, line of product, type of product and distribution channel, then, considering portfolio effects, the applied SCS is defined. Finally, based on the SCS chosen, the set of KPIs to be used in each process are selected, as suggested in Table 8.

\section{Conclusions and future developments}

This article stems from the desire of companies in the luxury fashion industry, which operates within a highly dynamic context, to implement SCS strongly linked to action. Quite often, it is the inability to connect SCS to the actions, and the consequent lack of attention in the implementation phase, that result in failure pertaining to the concretization of initiatives and ideas, even if supported by apparently coherent plans.

Within this context, the request to monitor KPIs arises in order to understand whether the business strategy has been translated into operational levers. The difficulty encountered by companies resides in identifying which KPIs need to be measured, according to the SCS implemented by the company.

Therefore, the objective of this article was to investigate the alignment between the SCS implemented within fashion luxury companies and the KPIs monitored within them. 


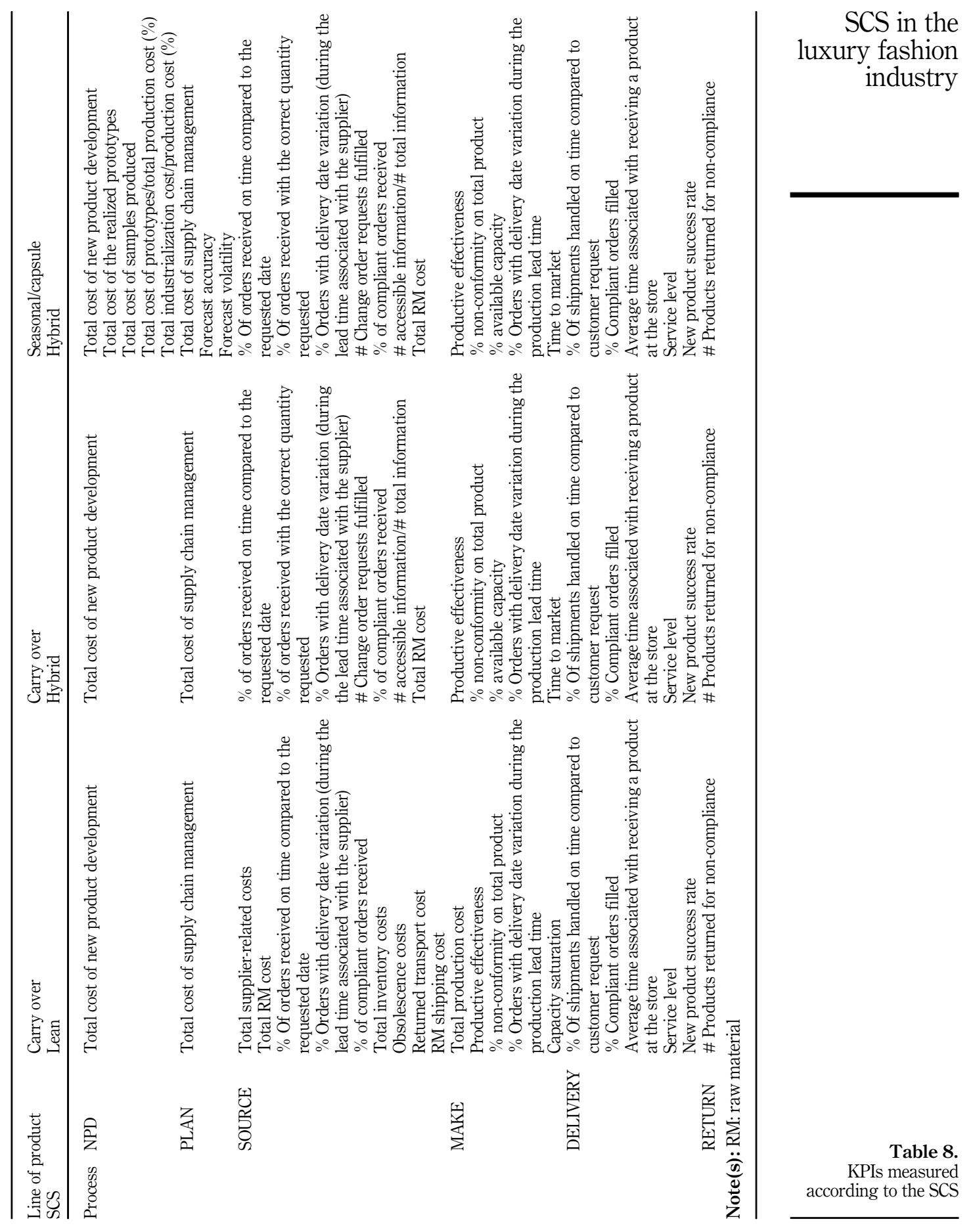


The requisite of the present study was to provide answers to the two aforementioned research questions.

(1) Regarding RQ1, although the literature suggests adopting a lean strategy for carry over products, the case studies have shown that this type of strategy is not always adopted. As far as seasonal products are concerned, a hybrid SCS, consisting of a lean phase, followed by a subsequent agile phase, appears to be the approach adopted. This result was confirmed from both the single case analysis and by the cross-case analysis. Finally, the capsule product was shown to follow the same strategy used for seasonal products, despite the fact that the literature recommends an agile SCS for these types of products that focuses on reactivity and flexibility in order to meet customer demand.

(2) From the RQ2, through the literature analysis, it was possible to identify the KPIs measured by companies and to subsequently integrate them with those present in the SCOR and DCOR model. These indicators were associated with the strategies identified in DR1 and compared with those monitored by the companies involved in the case study through the use of questionnaires and direct interviews.

The scope and results of the overall research are broader than those presented in the previous sections. In terms of managerial implications, one of the most interesting contributions is the identification of the product line as a driver influencing the SCS choice and the different approaches to measuring KPIs. Managers could adopt the listed elements in order to define the most suitable SCS for the specific targets of the brand. Since this decision is strictly related to the company positioning on the market, it is important to fully understand and identify the set of drivers that the brands pursue on the market. As a consequence, it is possible to evaluate the actual SCS, in terms of structure and practices. This will permit the company to understand in which aspects it is aligned toward the KPIs identified in literature and where not, allowing those aspects to be revised.

A limitation of the present study is related to the sample dimension and composition. While case studies permitted us to understand and compare different SCS in the fashion luxury industry, a wider sample should be applied in order to evaluate different sectors, as the fast fashion or the mass market. On the other hand, sample could be extended including other luxury segments, as jewels, boat or cars. Despite this fact, the present study is a starting point for further research in these directions. Last, the study and the sample could be extended to include additional types of fashion luxury products in order to understand different approaches to SCS and KPIs derived from different type of distribution channel and product typology.

\section{References}

Agarwal, A., Shankar, R. and Tiwari, M.K. (2007), "Modeling agility of supply chain", Industrial Marketing Management, Vol. 36 No. 4, pp. 443-457.

Badri, M.A., Davis, D. and Davis, D. (1995), "A study of measuring the critical factors of quality management”, International Journal of Quality and Reliability Management, Vol. 12 No. 2, pp. 36-53.

Battista, C. and Schiraldi, M.M. (2013), "The logistic maturity model: application to a fashion company", International Journal of Engineering Business Management, Vol. 5 No. SPL.ISSUE, doi: $10.5772 / 56838$.

Beamon, B.M. (1999), "Measuring supply chain performance”, International Journal of Operations and Production Management, Vol. 19 No. 3, pp. 275-292.

Bhagwat, R. and Sharma, M.K. (2007), "Performance measurement of supply chain management: a balanced scorecard approach”, Computers and Industrial Engineering, Vol. 53 No. 1, pp. 43-62. 
Bruce, M., Daly, L. and Towers, N. (2004), "Lean or agile: a solution for supply chain management in the textiles and clothing industry?", International Journal of Operations and Production Management, Emerald Group Publishing, Vol. 24 Nos 1-2, pp. 151-170.

Brun, A., Caniato, F., Caridi, M., Castelli, C., Miragliotta, G., Ronchi, S. and Spina, G. (2008), "Logistics and supply chain management in luxury fashion retail: empirical investigation of Italian firms", International Journal of Production Economics, Vol. 114 No. 2, pp. 554-570.

Brun, A. and Castelli, C. (2008), "Supply chain strategy in the fashion industry: developing a portfolio model depending on product, retail channel and brand", International Journal of Production Economics, Vol. 116 No. 2, pp. 169-181.

Brun, A., Castelli, C. and Karaosman, H. (2017), "A focused supply chain strategy for luxury fashion management", Journal of Fashion Marketing and Management, Emerald Group Publishing, Vol. 21 No. 4, pp. 544-563.

Cagnazzo, L., Taticchi, P. and Brun, A. (2010), "The role of performance measurement systems to support quality improvement initiatives at supply chain level", International Journal of Productivity and Performance Management, Emerald Group Publishing, Vol. 59 No. 2, pp. 163-185.

Cai, J., Liu, X., Xiao, Z. and Liu, J. (2009), "Improving supply chain performance management: a systematic approach to analyzing iterative KPI accomplishment", Decision Support Systems, Vol. 46 No. 2, pp. 512-521.

Caniato, F., Caridi, M., Castelli, C. and Crippa, L. (2008), "Demand and retail management in luxury fashion industries", Vol. 12 No. 3.

Caniato, F., Caridi, M., Castelli, C.M. and Golini, R. (2009), "A contingency approach for SC strategy in the Italian luxury industry: do consolidated models fit?", International Journal of Production Economics, Elsevier, Vol. 120 No. 1, pp. 176-189.

Chae, B. (2009), "Developing key performance indicators for supply chain: an industry perspective", Supply Chain Management, Vol. 14 No. 6, pp. 422-428.

Chan, F.T.S. (2003), "Performance measurement in a supply chain", The International Journal of Advanced Manufacturing Technology, Vol. 21 No. 7, pp. 534-548.

Christopher, M. (2000), “The agile supply chain: competing in volatile markets”, Industrial Marketing Management, Elsevier, Vol. 29 No. 1, pp. 37-44.

Christopher, M. and Peck, H. (2004), "Building the resilient supply chain”, The International Journal of Logistics Management, Vol. 15 No. 2, pp. 1-14.

Christopher, M. and Towill, D.R. (2002), "Developing market specific supply chain strategies", The International Journal of Logistics Management, Vol. 13 No. 1, pp. 1-14.

Christopher, M., Lowson, R. and Peck, H. (2004), "Creating agile supply chains in the fashion industry", International Journal of Retail and Distribution Management, Vol. 32 No. 8, pp. 367-376.

De Felice, F. and Petrillo, A. (2013), "Key success factors for organizational innovation in the fashion industry", International Journal of Engineering Business Management, Vol. 5 No. SPL.ISSUE, doi: $10.5772 / 56882$.

De Toni, A. and Tonchia, S. (2001), "Performance measurement systems models, characteristics and measures", International Journal of Operations and Production Management, Emerald Group Publishing, Vol. 21 Nos 1-2, pp. 46-70.

Dombrowski, U., Schmidtchen, K. and Ebentreich, D. (2013), "Balanced key performance indicators in product development", International Journal of Materials, Mechanics and Manufacturing, Vol. 1 No. 1, pp. 27-31, - Cerca con Google”, International Journal of Materials, Mechanics and Manufacturing.

Eisenhardt, K.M. (1989), "Building theories from case study research", The Academy of Management Review, Vol. 14 No. 4, p. 532, The Academy of Management. 
Flin, R., Mearns, K., O'Connor, P. and Bryden, R. (2000), "Measuring safety climate: identifying the common features", Safety Science, Vol. 34, pp. 177-192, Elsevier.

Ghalayini, A.M., Noble, J.S. and Crowe, T.J. (1997), "An integrated dynamic performance measurement system for improving manufacturing competitiveness", International Journal of Production Economics, Elsevier, Vol. 48 No. 3, pp. 207-225.

Gosselin, M. (2005), "An empirical study of performance measurement in manufacturing firms", International Journal of Productivity and Performance Management, Vol. 54 Nos 5-6, pp. 419-437.

Gunasekaran, A., Patel, C. and McGaughey, R.E. (2004), "A framework for supply chain performance measurement”, International Journal of Production Economics, Vol. 87, pp. 333-347.

Hill, T. (1995), "Manufacturing strategy: text and cases".

Huang, S.H., Uppal, M. and Shi, J. (2002), "A product driven approach to manufacturing supply chain selection”, Supply Chain Management: An International Journal, Vol. 7 No. 4, pp. 189-199.

Ishaq Bhatti, M. and Awan, H.M. (2014), "The key performance indicators (KPIs) and their impact on overall organizational performance", Quality and Quantity, Kluwer Academic Publishers, Vol. 48 No. 6, pp. 3127-3143.

Ittner, C.D. and Larcker, D.F. (1998), "Are nonfinancial measures leading indicators of Financial performance? An analysis of customer satisfaction”, Journal of Accounting Research, Vol. 36, p. 1, JSTOR.

Kumar, J. (2013), "Maintenance performance metrics for manufacturing industry", International Journal of Research in Engineering and Technology, Vol. 02 No. 02, pp. 136-142.

Kumar Hurreeram, D., Devkumar, C.S., Callychurn, D.S., Soobhug, K. and Hurreeram, D.K. (2014), "Key success factors for the apparel manufacturing industry: a case study at company X $\mathrm{PhD}$ project view project productivity assessment view project key success factors for the apparel manufacturing industry: a case study at company X” No. July, doi: 10.13140/2.1. 4944.1285.

Lamming, R., Johnsen, T., Zheng, J. and Harland, C. (2000), "An initial classification of supply networks", International Journal of Operations and Production Management, Vol. 20 No. 6, pp. 675-691.

Lapide, L. (2000), "What about measuring supply chain performance? [White paper]", Supply Chain, Vol. 24 No. 7, pp. 287-297.

Lee, H.L. (2003), "Aligning supply chain strategies with product uncertainties”, IEEE Engineering Management Review, Institute of Electrical and Electronics Engineers, Vol. 31 No. 2, pp. 26-34.

Leong, G.K., Snyder, D.L. and Ward, P.T. (1990), "Research in the process and content of manufacturing strategy", Omega, Vol. 18 No. 2, pp. 109-122, Pergamon.

Lin, C.T., Chiu, H. and Chu, P.Y. (2006), "Agility index in the supply chain”, International Journal of Production Economics, Elsevier, Vol. 100 No. 2, pp. 285-299.

Luxury Fashion - Worldwide | Statista Market Forecast". (2021), available at: https:/www.statista. $\mathrm{com} /$ outlook/cmo/luxury-goods/luxury-fashion/worldwide?currency=USD (accessed 1 September 2021).

Macchion, L., Moretto, A., Caniato, F., Caridi, M., Danese, P. and Vinelli, A. (2015), "Production and supply network strategies within the fashion industry", International Journal of Production Economics, Elsevier, Vol. 163, pp. 173-188.

Maimbo, H. and Pervan, G. (2005), "Designing a case study protocol for application in IS research", in 9th Pacific Asia Conference on Information Systems: I.T. and Value Creation, PACIS 2005, pp. 1281-1292.

Mason-Jones, R., Naylor, B. and Towill, D.R. (2000), "Engineering the leagile supply chain", International Journal of Agile Management Systems, Emerald, Vol. 2 No. 1, pp. 54-61. 
Mattila, H., King, R. and Ojala, N. (2002), "Retail performance measures for seasonal fashion”, Journal of Fashion Marketing and Management, Vol. 6 No. 4, pp. 340-351.

McColl, J. and Moore, C. (2011), "An exploration of fashion retailer own brand strategies", Journal of Fashion Marketing and Management, Emerald Publishing, Vol. 15 No. 1, pp. 91-107.

Mearns, K., Whitaker, S.M. and Flin, R. (2003), "Safety climate, safety management practice and safety performance in offshore environments", Safety Science, Elsevier, Vol. 41 No. 8, pp. 641-680.

Miles, M.B. and Huberman, A.M. (1984), "Drawing valid meaning from qualitative data: toward a shared craft", Educational Researcher, Sage Publications: Thousand Oaks, CA, Vol. 13 No. 5, pp. 20-30.

Moore, M. and Fairhurst, A. (2003), "Marketing capabilities and firm performance in fashion retailing", Journal of Fashion Marketing and Management, Vol. 7 No. 4, pp. 386-397.

Mora, E. (2006), "Collective production of creativity in the Italian fashion system", Poetics, Vol. 34 No. 6, pp. 334-353.

Naylor, J.B., Naim, M.M. and Berry, D. (1999), "Leagility: integrating the lean and agile manufacturing paradigms in the total supply chain", International Journal of Production Economics, Vol. 62, pp. 107-118.

Neely, A., Gregory, M. and Platts, K. (2005), "Performance measurement system design: a literature review and research agenda", International Journal of Operations and Production Management.

Newman, A.J. and Foxall, G.R. (2003), "In-store customer behaviour in the fashion sector: some emerging methodological and theoretical directions", International Journal of Retail and Distribution Management, Vol. 31 No. 11, pp. 591-600.

Otto, A. and Kotzab, H. (2003), "Does supply chain management really pay? Six perspectives to measure the performance of managing a supply chain”, European Journal of Operational Research, Vol. 144 No. 2, pp. 306-320.

Papakiriakopoulos, D. and Pramatari, K. (2010), "Collaborative performance measurement in supply chain”, Industrial Management and Data Systems, Vol. 110 No. 9, pp. 1297-1318.

Parmenter, D. (2015), Key Performance Indicators: Developing, Implementing, and Using Winning KPIs, John Wiley \& Sons.

Pinna, C., D’Avolio, E., Bandinelli, R., Terzi, S. and Rinaldi, R. (2017), "Product development kpis: a case study analysis in food and fashion companies", in Proceedings of the Summer School Francesco Turco, 2017-September, pp. 129-135.

Piotrowicz, W. and Cuthbertson, R. (2015), "Performance measurement and metrics in supply chains: an exploratory study", International Journal of Productivity and Performance Management, Emerald Group Publishing, Vol. 64 No. 8, pp. 1068-1091.

Ponticelli, S., Mininno, V., Dulmin, R. and Aloini, D. (2013), "Supply chain implications for one-off luxury products: cases from the yacht industry", International Journal of Retail and Distribution Management, Emerald Group Publishing, Vol. 41 Nos 11-12, pp. 1008-1029.

Power, D.J., Sohal, A.S. and Rahman, S.U. (2001), "Critical success factors in agile supply chain management an empirical study", International Journal of Physical Distribution and Logistics Management, Emerald Group Publishing, Vol. 31 No. 4, pp. 247-265.

Qi, Y., Boyer, K.K. and Zhao, X. (2009), "Supply chain strategy, product characteristics, and performance impact: evidence from Chinese manufacturers", Decision Sciences, Vol. 40 No. 4, pp. 667-695.

Rigaud-Lacresse, E. and Pini, F.M. (2017), New Luxury Management: Creating and Managing Sustainable Value across the Organization, Springer International Publishing, Cham.

Sadler-Smith, E., Spicer, D.P. and Chaston, I. (2001), "Learning orientations and growth in smaller firms", Long Range Planning, Vol. 34 No. 2, pp. 139-158.

Sellitto, M.A., Pereira, G.M., Borchardt, M., Da Silva, R.I. and Viegas, C.V. (2015), “A SCORbased model for supply chain performance measurement: application in the footwear 
industry", International Journal of Production Research, Taylor and Francis, Vol. 53 No. 16, pp. 4917-4926.

Shepherd, C. and Günter, H. (2011), "Measuring supply chain performance: current research and future directions", Behavioral Operations in Planning and Scheduling, Springer Berlin Heidelberg, pp. 105-121.

Sherman, J.D., Berkowitz, D. and Souder, W.E. (2005), "New product development performance and the interaction of cross-functional integration and knowledge management", Journal of Product Innovation Management, Vol. 22 No. 5, pp. 399-411.

Slack, N., Chambers, S. and Johnston, R. (2010), Operations Management/Nigel Slack, Stuart Chambers, Robert Johnston.

Stewart, G. (1995), "Supply chain performance benchmarking study reveals keys to supply chain excellence", Logistics Information Management, Emerald, Vol. 8 No. 2, pp. 38-44.

Thilakarathna, R.H., Dharmawardana, M.N. and Rupasinghe, T. (2015), “The supply chain operations reference (SCOR) model: a systematic review of literature from the apparel industry", SSRN Electronic Journal, doi: 10.2139/ssrn.2699886.

Utterback, J.M. and Abernathy, W.J. (1975), "A dynamic model of process and product innovation”, Omega, Vol. 3 No. 6, pp. 639-656, Pergamon.

Van Hoek, R.I., Harrison, A. and Christopher, M. (2001), "Measuring agile capabilities in the supply chain", International Journal of Operations and Production Management, Emerald Group Publishing, Vol. 21 Nos 1-2, pp. 126-147.

Vona, R. (2003), "Marketing E PRODUZIONE NEL PRONTO-MODA : IL 'MODELLO ' ZARA”, pp. 28-29.

Vonderembse, M.A., Uppal, M., Huang, S.H. and Dismukes, J.P. (2006), "Designing supply chains: Towards theory development", International Journal of Production Economics, Vol. 100 No. 2, pp. 223-238.

Wang, X., Chan, H.K., Yee, R.W.Y. and Diaz-Rainey, I. (2012), “A two-stage fuzzy-AHP model for risk assessment of implementing green initiatives in the fashion supply chain", International Journal of Production Economics, Vol. 135 No. 2, pp. 595-606.

Wang, G., Huang, S.H. and Dismukes, J.P. (2004), "Product-driven supply chain selection using integrated multi-criteria decision-making methodology", International Journal of Production Economics, Vol. 91 No. 1, pp. 1-15.

White, G.P. (1996), "A survey and taxonomy of strategy-related performance measures for manufacturing", International Journal of Operations and Production Management, MCB UP Ltd, 1 March.

Wortmann, J.C. (1992), "Production management systems for one-of-a-kind products", Computers in Industry, Vol. 19 No. 1, pp. 79-88.

Yeh, T.-M., Pai, F.-Y., Yang, C.-C., Yeh, T.-M., Pai, F.-Y. and Yang, C.-C. (2010), "Performance improvement in new product development with effective tools and techniques adoption for high-tech industries”, Qual Quant, Vol. 44, pp. 131-152.

\section{Appendix: - Questionnaire}

The questionnaire is made in order to collect data to identify the most suitable supply chain strategy (SCS) and performance measures more adopted in luxury fashion supply chain.

\section{Supply chain strategy (SCS)}

Open-ended questions regarding SCS.

Which is your company brand positioning?

How many lines are managed within the company? 
Which are the sales channels of your company?

What is/are the main type of products you managed?

(1) For the type of product mentioned above, do you manage carry over, seasonal and capsules/ special projects or other types of products?

(2) If you manage both carry over and seasonal product, what is the percentage of carry over rather than seasonal?

For each type of distribution channel, type and line of products:

(1) how do you manage the purchase of raw materials?

- There is a diversification for each parameter (distribution channel, type and line of products)?

- There are other parameters you consider?

(2) For each combination of parameter define the type of production (Make to Stock, Make to Order etc.)?

What are the criteria of choice of the subcontractors and what are the motivations of these strategic choices (decentralization to external partners, etc.)?

(1) In shoring, outsourcing or offshoring?

- There is a diversification in the strategic choices for any of the above parameters (distribution channel, type and line of products)?

(2) In case of in shore suppliers, what are the reasons? (dimensions of the lot, logistic management, short times of delivery, transport costs, high quality)

- There is a diversification in the strategic choices for any of the above parameters (distribution channel, type and line of products)?

(3) In case of offshore suppliers, what are the reasons? (lower costs, greater availability of materials)

- There is a diversification in the strategic choices for any of the above parameters (distribution channel, type and line of products)?

(4) How do you manage supplier orders? For example, according to some order management criteria like delivery time, reorder point, economic lot or just in time.

- There is a diversification in the strategic choices for any of the above parameters (distribution channel, type and line of products)?

\section{Key performance indicators (KPIs)}

In the following tables are listed the key performance indicators (KPIs) coming from the literature review.

(1) The column "Utilization": if each performance measure is actually used by your company;

(2) The column "Importance": specify the degree of importance of the indicator. 


IJPPM
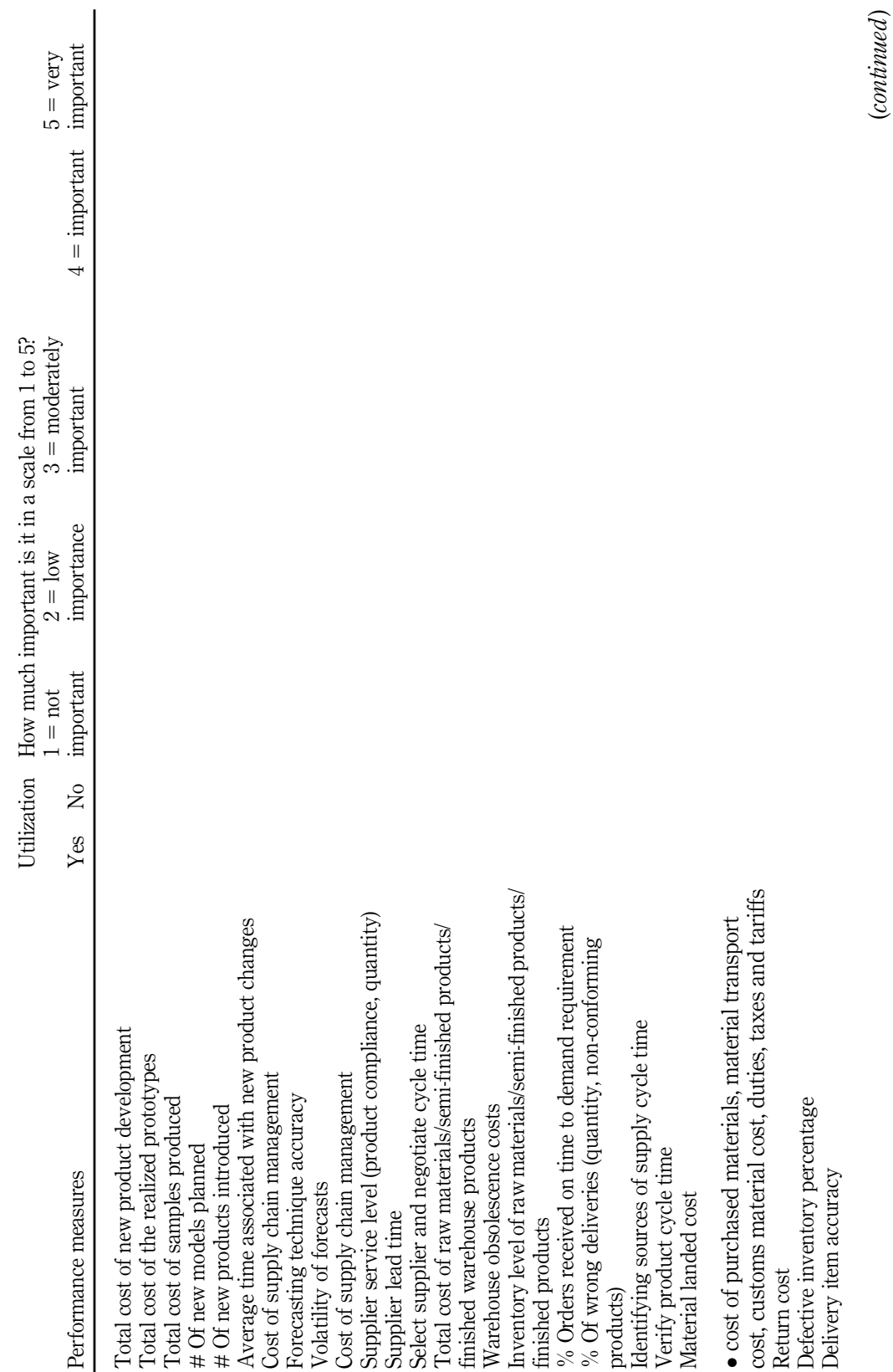

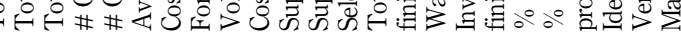

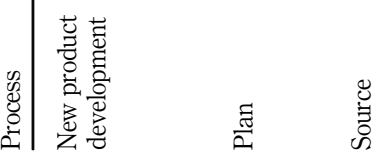




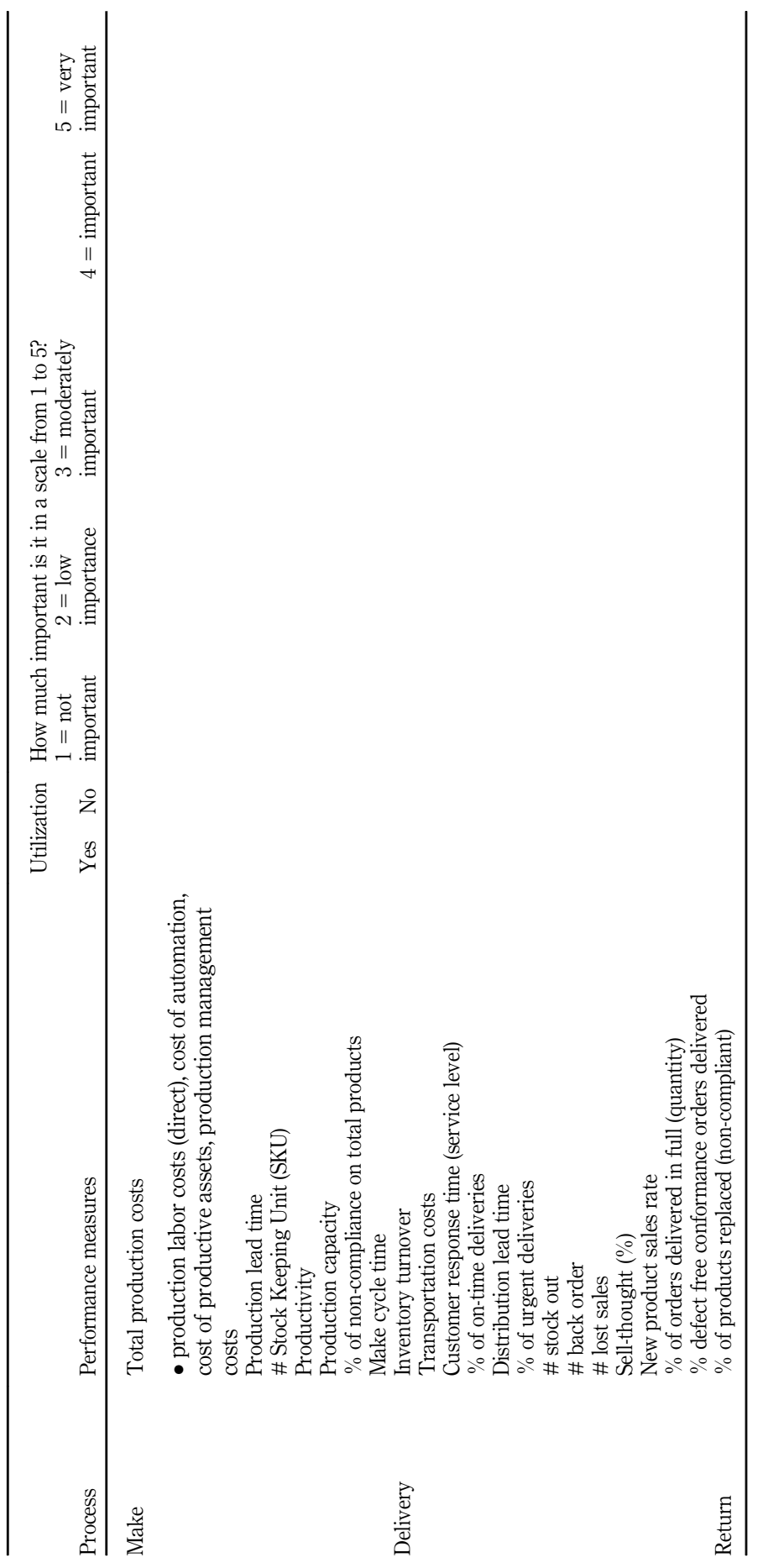

SCS in the luxury fashion industry 
About the authors

Bianca Bindi graduated in 2016 in Mechanical Engineering at the University of Florence and she earned her $\mathrm{Ph} . \mathrm{D}$. at the same University in 2020. Currently is a research fellow at the Industrial Engineering Department of the University of Florence. During her Ph.D., she carried out both research and consulting activities in the field of supply chain optimization and radio-frequency technologies (e.g. RFId, NFC). Moreover, she spent a period within a consulting company supporting them in the introduction of a new ERP in a fashion company.

Romeo Bandinelli is an Assistant Professor at University of Florence, Department of Industrial Engineering. He graduated in 2002 in Mechanical Engineering at University of Florence, where he earned in 2006 the Ph.D. title in Industrial Engineering and Reliability. He is the author of more than 80 publications on proceedings and international journals. He is member of the Editorial Board of the International Journal of Product Lifecycle Management and program chair of the scientific committee of the IT4Fashion congress. He is member of the IFIP 5.1 "Global Product development for the whole lifecycle". Romeo Bandinelli is the corresponding author and can be contacted at: romeo.bandinelli@ unifi.it

Virginia Fani graduated in 2014 in Industrial Engineering at Politecnico di Milano and she earned her Ph.D. at the University of Florence in 2019. Currently is a research fellow at the Industrial Engineering Department of the University of Florence. During her postgraduate course, the issues she is dealing with are related to production processes optimization along the supply chain, with particular focus on the peculiarities that the fashion companies have to face with. She is the author of several blind reviewed papers on proceedings and international journal.

Margherita Emma Paola Pero, Ph.D. is Associate Professor at Department of Management, Economics and Industrial Engineering of Politecnico di Milano. She teaches Business processes reengineering, operations and supply chain management at the School of Management of Politecnico di Milano. She is the director of Flex MBA program at MIP - Politecnico di Milano Graduate School of Business. She is the author of more than 100 papers at national and international level. Her main research interests are related to production planning, supply chain design and management and supply chain management-new product development coordination.

For instructions on how to order reprints of this article, please visit our website:

www.emeraldgrouppublishing.com/licensing/reprints.htm

Or contact us for further details: permissions@emeraldinsight.com 